\title{
Methane Production and Oxidation in Mangrove Soils Assessed by Stable Isotope Mass Balances
}

\author{
Salvador Sánchez-Carrillo ${ }^{1, *}$, Jaime Garatuza-Payan ${ }^{2}$, Raquel Sánchez-Andrés ${ }^{3}$, Francisco J. Cervantes ${ }^{4}{ }^{\circledR}$, \\ María Carmen Bartolomé ${ }^{5}$, Martín Merino-Ibarra ${ }^{6}\left[\right.$ and Frederic Thalasso ${ }^{7}$
}

1 Department Biogeochemistry and Microbial Ecology, Museo Nacional de Ciencias Naturales-CSIC (MNCN-CSIC), Serrano 115 Bis, E-28006 Madrid, Spain

2 Department Water and Environmental Sciences, Instituto Tecnológico de Sonora (ITSON), 5 de Febrero 818 Sur, Col. Centro, Ciudad Obregón CP. 85000, Sonora, Mexico; garatuza@itson.edu.mx

3 SpatialTools, Clara del Rey 79, E-28002 Madrid, Spain; spatialtools@gmail.com

4 Laboratory for Research on Advanced Processes for Water Treatment, Engineering Institute, Campus Juriquilla, Universidad Nacional Autónoma de México (UNAM), Blvd. Juriquilla 3001, Juriquilla CP. 76230, Querétaro, Mexico; fcervantesc@iingen.unam.mx

5 Faculty Química y Farmacobiología, Universidad Michoacana de San Nicolás de Hidalgo (UMICH),Tzinzuntzan 173, Col. Matamoros, Morelia CP. 58030, Michoacán, Mexico; carbarcam@hotmail.com

6 Instituto de Ciencias del Mar y Limnología, Universidad Nacional Autónoma de México (ICMyL-UNAM), Cto. Exterior s/n, Ciudad Universitaria, Del. Coyoacán, Ciudad de México CP. 04510, Mexico; mmerino@cmarl.unam.mx

7 Departamento de Biotecnología y Bioingeniería, Centro de Investigación y de Estudios Avanzados del Instituto Politécnico Nacional (Cinvestav-IPN), Av. IPN 2508, San Pedro Zacatenco, Gustavo A. Madero, Ciudad de México CP. 07360, Mexico; thalasso@cinvestav.mx

check for
updates

Citation: Sánchez-Carrillo, S.; Garatuza-Payan, J.; Sánchez-Andrés, R.; Cervantes, F.J.; Bartolomé, M.C.;

Merino-lbarra, M.; Thalasso, F.

Methane Production and Oxidation in Mangrove Soils Assessed by Stable Isotope Mass Balances. Water 2021, 13, 1867. https://doi.org/10.3390/ w13131867

Academic Editor: Thomas Meixner

Received: 26 May 2021

Accepted: 24 June 2021

Published: 4 July 2021

Publisher's Note: MDPI stays neutral with regard to jurisdictional claims in published maps and institutional affiliations.

Copyright: (c) 2021 by the authors. Licensee MDPI, Basel, Switzerland. This article is an open access article distributed under the terms and conditions of the Creative Commons Attribution (CC BY) license (https:// creativecommons.org/licenses/by/ $4.0 /)$.
* Correspondence: sanchez.carrillo@mncn.csic.es

\begin{abstract}
Considerable variability in methane production and emissions has been reported in mangroves, explained by methane inhibition and oxidation. In this study, soil pore waters were collected from mangrove forests located in the Gulf of California (Mexico) exposed to shrimp farm disturbance. The $\delta^{13} \mathrm{C}$ of dissolved inorganic carbon (DIC) and $\mathrm{CH}_{4}$ were analyzed along with the $\delta^{13} \mathrm{C}$ of the soil organic matter to assess the proportion of $\mathrm{CO}_{2}$ derived from methanogenesis, its main pathway, and the fraction of methane oxidized. We performed slurry incubation experiments to fit the isotope-mass balance approach. Very low stoichiometric ratios of $\mathrm{CH}_{4} / \mathrm{CO}_{2}$ were measured in pore waters, but isotope mass balances revealed that $30-70 \%$ of the total $\mathrm{CO}_{2}$ measured was produced by methanogenesis. Mangrove soils receiving effluent discharges shifted the main methanogenesis pathway to $\mathrm{CO}_{2}$ reduction because of an increase in refractory organic matter. Isotope-mass balances of incubations indicated that methane was mainly oxidized by anaerobic oxidation of methane (AOM) coupled to sulfate reduction, and the increase in recalcitrant organic matter should fuel AOM as humus serves as a terminal electron acceptor. Since methanogenesis in mangrove soils is strongly controlled by the oxygen supply provided by mangrove roots, conservation of the forest plays a crucial role in mitigating greenhouse gas emissions.
\end{abstract}

Keywords: mangroves; methanogenesis; isotope-mass balance; $\mathrm{CO}_{2} ; \mathrm{CH}_{4}$

\section{Introduction}

Wetlands are the primary source of non-anthropogenic methane to the atmosphere [1]. Methanogenesis is considered the dominant pathway for the decomposition of organic matter in freshwater wetlands [2], whereas sulfate-reducing bacteria outcompete methanogens for common substrates in coastal areas and saline wetlands [3]. In coastal wetlands, tidal seawater is thought to provide enough sulfate-to-sulfate-reducing bacteria with much higher affinity and competition for $\mathrm{H}_{2}$ and acetate than methanogens [4,5]. It would 
then explain the relatively low methane emission rates measured in many coastal wetlands, including mangrove swamps, compared to freshwater wetlands [3,6-8]. However, methane fluxes comparable to those measured in freshwater wetlands have also been measured in several mangrove wetlands worldwide [9-13], where the co-existence of high concentrations of sulfate and methane have been detected in sediment pore waters. Whereas high methane fluxes are explained by the use of non-competitive substrates by methanogens $[14,15]$, low methane fluxes are mainly explained by methanogenesis inhibition and, to a lesser extent, by anaerobic methane oxidation (AOM) linked to sulfate reduction, which might consume a significant fraction of $\mathrm{CH}_{4}[16,17]$. Unfortunately, because methanogenesis and AOM zones overlap in the soil profile, it is impossible to spatially segregate each chemical involved to assess the balance between methane production and consumption in these coastal wetlands.

In waterlogged soils, methanogenesis produces an equimolar net amount of $\mathrm{CO}_{2}$ and $\mathrm{CH}_{4}[18,19]$. In wetland soils, it is usual to find in pore waters concentrations of dissolved inorganic carbon DIC (DIC $=\Sigma \mathrm{CO}_{2}$ ) greater than those of $\mathrm{CH}_{4}$, suggesting that other mechanisms of $\mathrm{CO}_{2}$ production can be more important than methanogenesis $[2,19]$ or that a significant amount of $\mathrm{CH}_{4}$ is oxidized. High $\mathrm{CO}_{2} / \mathrm{CH}_{4}$ ratios have been observed in mangrove soil pore waters, and it was thought to be mainly due to methanogenesis inhibition [11]. However, there is no evidence that AOM was negligible in depleting the $\mathrm{CH}_{4}$ concentration because no method could detect it.

During both methanogenesis pathways (hydrogenotrophic and acetoclastic), the $\delta^{13} \mathrm{C}$ of organic matter $\left(\delta^{13} \mathrm{C}_{-} \mathrm{OM}\right)$ is fractionated to form an enriched $\delta^{13} \mathrm{C}_{-}-\mathrm{CO}_{2 \text {-meth }}$ and a depleted $\delta^{13} \mathrm{C}_{-} \mathrm{CH}_{4}$ [2]. The isotopic fractionation factors occurring with the formation of $\delta^{13} \mathrm{C}_{-}-\mathrm{CO}_{2-\mathrm{OM}}$ derived from the fermentation of organic matter or other forms of respiration are almost negligible [19]. These differences on the isotopic fractionations allows the $\delta^{13} \mathrm{C}$ signatures of the different substances and compounds related to organic matter degradation to be tracers of the metabolic processes [20]. Because of the differences in $813 \mathrm{C}$ signatures, the isotopic mass balance approach has been used successfully to trace methanogenesis in freshwater wetlands (e.g., [19]), and it may be helpful to understand how methanogenesis and AOM processes operate in coastal wetlands.

Ecosystem productivity was early considered the primary driver of methane emissions in wetlands [21], and several studies have shown that $\mathrm{CH}_{4}$ emissions positively correlate with productivity variables, such as total phosphorus (TP) and chlorophyll-a [22-25], even at global scales [26]. However, the microbial processes in mangrove soils have been cited for having strong resilience towards disturbances [27]. Among many factors, anthropogenic nutrient inputs, changes in the amount of freshwater inputs as well as in plant cover have been cited to increase the methane emission in mangroves $[6,10,28,29]$. Shrimp farms, which are a typical landscape in the tropical coastal area, often discharge untreated effluents containing organic refractory wastes and unassimilated inorganic fertilizers [30,31]. Although numerous studies have reported the effects of shrimp-farm effluents on water quality, eutrophication, biodiversity, and food webs in coastal lagoons and near-shore marine habitats (e.g., [32-34]), little attention has been paid to the impact on methane emissions. For instance, nutrient-rich shrimp farm effluents that reach the mangroves can stimulate organic matter decomposition [35], deplete the amount of sulfate [15], and increase the degrees of iron pyritization (formation of iron sulfides; [36]). The combination of factors suggest shrimp farm effluents may trigger methane production and emissions, but it has been poorly studied.

The objective of this study was to comparatively quantify through an isotopic mass balance the main pathway (aerobic/anaerobic) of organic matter degradation in mangrove soils and the partition between the production/oxidation of methane from mangrove forests located in the arid tropic of the Gulf of California (Mexico) subjected to different degrees of shrimp farm disturbance (pristine and closeness to shrimp farm effluents) and tidal influence (by the distance to the shoreline as influenced by salinity and sulfate availability). To this end, we used mini piezometers to extract soil pore water and measure 
the $\delta^{13} \mathrm{C}$ of DIC and $\mathrm{CH}_{4}$, along with the $\delta^{13} \mathrm{C}$ of the soil organic matter. We also performed sediment slurry incubation experiments to carry out isotope-mass balance calculations on closed systems to compare results with the isotope-mass balance approach computed using field data. Our results provide basic quantitative information on methane dynamics and organic matter degradation in disturbed mangroves by shrimp farm activity, which can be useful for the management of greenhouse gas emissions from coastal wetlands under global warming.

\section{Materials and Methods}

\subsection{Study Site}

The study was conducted in semi-arid mangrove forests of the Gulf of California (Mexico), subjected to different environmental disturbance (Figure 1): (a) Estero Los Mélagos $\left(27^{\circ} 10^{\prime} 2^{\prime \prime} \mathrm{N}\right.$ and $\left.110^{\circ} 17^{\prime} 31^{\prime \prime} \mathrm{O}\right)$, a degraded coastal lagoon receiving sewage discharges from shrimp-farm effluents combined with a small fraction of urban wastewater, in three stands located at different distances from the effluent (MEL-1, close to the effluent, and MEL-2 and MEL-3, further from the point of discharge); (b) Estero Santo Domingo ( $27^{\circ} 8^{\prime} 58^{\prime \prime}$ $\mathrm{N}$ and $110^{\circ} 15^{\prime} 48^{\prime \prime} \mathrm{O}$ ), in two stands, one located close to a shrimp effluent (DOM-1) and another far, although close to the shrimp farms (DOM-2); and (c) Estero Los Algodones (ALG; $27^{\circ} 39^{\prime} 29^{\prime \prime} \mathrm{N}$ and $110^{\circ} 35^{\prime} 58^{\prime \prime} \mathrm{O}$ ), with mangroves surrounding an almost pristine coastal lagoon dedicated to the artisanal fishery in four points: two close to the littoral (ALG-3 and ALG-4) and two others further away (ALG-1 and ALG-2). Because this coastal area is microtidal [37], we ensured that all sampling points were exposed to tidal flooding during the spring tides. At MEL and DOM sites, mangrove soils were mainly sandy or sandyloam, whereas ALG was mostly clay-silty soils (Table 1). Vegetation in all studied forests comprised monospecific stands of Avicennia germinans with occasional Rhizophora mangle patches occurring at the shoreline fringe of lagoons and scattered patches of Salicornia virginica and Batis maritima (Sánchez-Carrillo, unpublished data; Table 1.

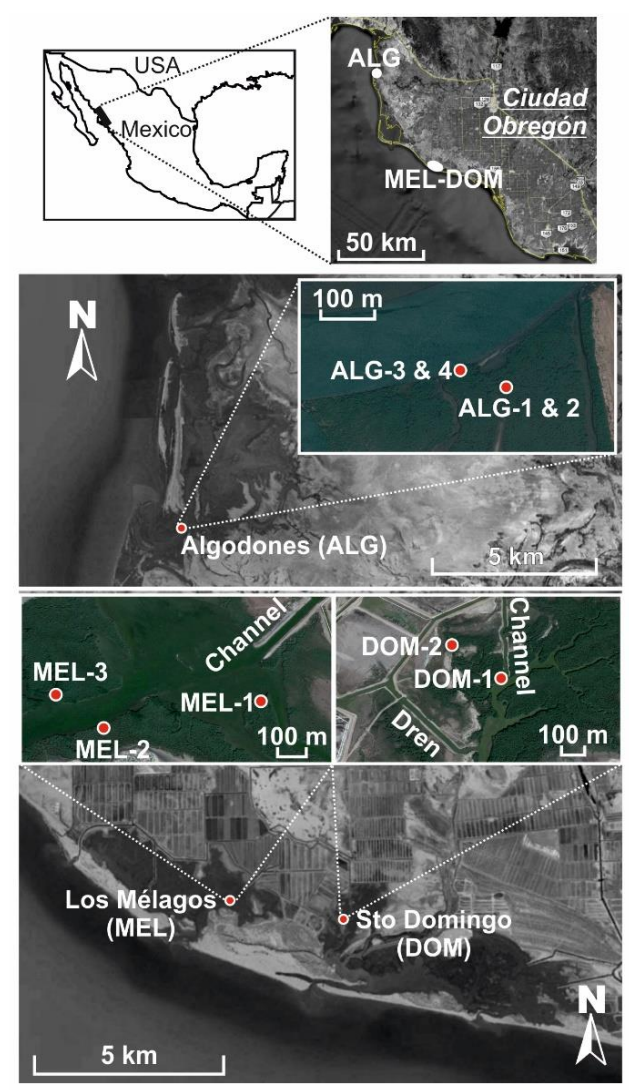

Figure 1. Map showing the studied Mexican mangrove wetlands in the Gulf of California and detailed location of the sampling sites. 


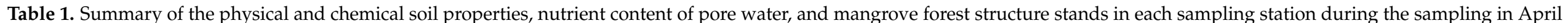

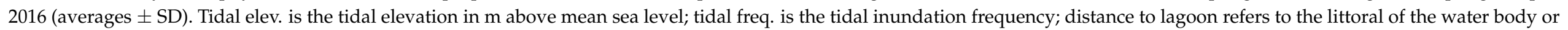

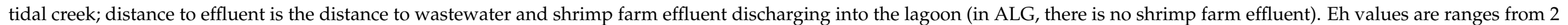
$\mathrm{cm}$ to $14 \mathrm{~cm}$ of soil depth.

\begin{tabular}{|c|c|c|c|c|c|c|c|c|c|}
\hline & MEL-1 & MEL-2 & MEL-3 & DOM-1 & DOM-2 & ALG-1 & ALG-2 & ALG-3 & ALG-4 \\
\hline Tidal elev. (mAMSL) & 0.15 & 0.17 & 0.15 & 0.16 & 0.61 & 0.6 & 0.58 & 0.12 & 0.11 \\
\hline Tidal freq. (tides $\mathrm{d}^{-1}$ ) & 1.5 & 1.5 & 1.5 & 1.4 & 4.3 & 4.1 & 4.1 & 1.2 & 1.2 \\
\hline Distance to lagoon (m) & 2 & 2 & 2 & 2 & 50 & 55 & 55 & 2 & 2 \\
\hline \multicolumn{10}{|l|}{ Mangrovesoil: } \\
\hline Salinity $\left(\mathrm{g} \mathrm{kg}^{-1}\right)$ & $31.5 \pm 0.4$ & $40.2 \pm 0.9$ & $40.1 \pm 0.5$ & $30.4 \pm 0.8$ & $35.1 \pm 0.4$ & $34.7 \pm 0.7$ & $35.2 \pm 0.1$ & $34.7 \pm 0.3$ & $35.3 \pm 0.5$ \\
\hline Total organic carbon $(\%)$ & $2.1 \pm 0.06$ & $1.5 \pm 0.03$ & $2.1 \pm 0.07$ & $2.2 \pm 0.07$ & $0.6 \pm 0.002$ & $2.4 \pm 0.1$ & $3.3 \pm 0.12$ & $1.6 \pm 0.27$ & $2.1 \pm 0.03$ \\
\hline Total nitrogen $(\%)$ & $0.2 \pm 0.004$ & $0.1 \pm 0.001$ & $0.2 \pm 0.007$ & $0.2 \pm 0.003$ & $0.1 \pm 0.0001$ & $0.1 \pm 0.002$ & $0.2 \pm 0.006$ & $0.1 \pm 0.13$ & $0.2 \pm 0.0003$ \\
\hline$\delta^{13} \mathrm{C}$-Organic matter (\%o) & $-25 \pm 0.04$ & $-25.2 \pm 0.01$ & $-24.9 \pm 0.06$ & $-24.5 \pm 0.07$ & $-22 \pm 0.11$ & $-25.1 \pm 0.08$ & $-25.1 \pm 0.07$ & $-24.5 \pm 0.33$ & $-24.7 \pm 0.09$ \\
\hline Bulk density $\left(\mathrm{g} \mathrm{cm}^{-3}\right)$ & $1.57 \pm 0.01$ & $1.51 \pm 0.003$ & $1.59 \pm 0.01$ & $1.69 \pm 0.01$ & $1.69 \pm 0.002$ & $1.09 \pm 0.002$ & $1.09 \pm 0.002$ & $1.15 \pm 0.003$ & $1.09 \pm 0.01$ \\
\hline Sand/Silt/Clay (\%) & $55 / 20 / 25$ & $62 / 23 / 15$ & $58 / 24 / 18$ & $33 / 21 / 46$ & $29 / 39 / 32$ & $12 / 26 / 62$ & $14 / 33 / 53$ & $12 / 45 / 43$ & $16 / 41 / 43$ \\
\hline \multicolumn{10}{|l|}{ Soilpore water: } \\
\hline Eh redox potential $(\mathrm{mV})$ & -117 to -172 & -119 to -179 & -121 to -175 & -121 to -169 & -118 to -166 & -121 to -165 & -125 to -168 & -129 to -172 & -128 to -177 \\
\hline Ammonium $\left(\mathrm{mg} \mathrm{N}^{-1}\right)$ & 0.53 & 0.41 & 0.39 & 0.22 & 0.05 & 0.06 & 0.08 & 0.11 & 0.14 \\
\hline Nitrate $\left(\mathrm{mg} \mathrm{N} \mathrm{L}^{-1}\right)$ & $<0.01$ & $<0.01$ & $<0.01$ & 0.05 & 0.08 & $<0.01$ & $<0.01$ & $<0.01$ & $<0.01$ \\
\hline Total nitrogen $\left(\mathrm{mg} \mathrm{N} \mathrm{L}^{-1}\right)$ & 2.74 & 2.62 & 2.83 & 0.74 & 0.64 & 1.16 & 0.85 & 0.69 & 0.92 \\
\hline Sulfate $(\mathrm{mM})$ & 26.5 & 27.6 & 28.4 & 25.1 & 25.7 & 26.2 & 26.8 & 28.9 & 29.1 \\
\hline \multicolumn{10}{|l|}{ Mangroveforest stand: } \\
\hline Tree density (tree ha ${ }^{-1}$ ) & 2600 & 3300 & 2900 & 3100 & 900 & \multicolumn{2}{|c|}{3800} & \multicolumn{2}{|c|}{4400} \\
\hline Mean tree heigth (m) & $2.7 \pm 0.5$ & $3.1 \pm 0.8$ & $2.9 \pm 0.8$ & $2.7 \pm 0.8$ & $1.5 \pm 0.7$ & \multicolumn{2}{|c|}{$3.9 \pm 0.8$} & \multicolumn{2}{|c|}{$2.9 \pm 0.7$} \\
\hline Basal area $\left(\mathrm{m}^{2} \mathrm{ha}^{-1}\right)$ & 7.4 & 50.8 & 32.8 & 15.6 & 2.5 & \multicolumn{2}{|c|}{58.5} & \multicolumn{2}{|c|}{77.8} \\
\hline
\end{tabular}


Until the 1940s, the region was still nearly pristine [38], but, since then, the coastal zone has undergone rapid development, mainly based on shrimp farms built along the coast [39]. As a result, mangroves in this area are mainly net heterotrophic and P-limited systems [37], and they are subject to fast litter decomposition to compensate for the organic ecosystem deficit [40].

\subsection{Theoretical Considerations}

As pointed out by [18], the main methanogenesis pathways produce an equimolar net amount of $\mathrm{CO}_{2}$ and $\mathrm{CH}_{4}$ :

(a) acetate fermentation:

$$
\mathrm{CH}_{3} \mathrm{COOH} \rightarrow \mathrm{CH}_{4}+\mathrm{CO}_{2}
$$

and (b) $\mathrm{CO}_{2}$ reduction through the sum of two reactions:

$$
\begin{gathered}
\mathrm{CH}_{2} \mathrm{O}+2 \mathrm{H}_{2} \mathrm{O} \rightarrow 2 \mathrm{CO}_{2}+\mathrm{H}_{2} \\
\mathrm{CO}_{2}+4 \mathrm{H}_{2} \rightarrow \mathrm{CH}_{4}+2 \mathrm{H}_{2} \mathrm{O}
\end{gathered}
$$

with a net overall equation:

$$
\mathrm{CH}_{2} \mathrm{O} \rightarrow \mathrm{CH}_{4}+\mathrm{CO}_{2}
$$

Therefore, approximately equimolar amounts of $\mathrm{CH}_{4}$ and $\mathrm{CO}_{2}$ are produced during methanogenesis, and, from the organic matter $(\mathrm{OM})$ starting material, an isotopic fractionation is given in the $\delta^{13} \mathrm{C}-\mathrm{CH}_{4}$ and in the $\delta^{13} \mathrm{C}-\mathrm{CO}_{2-m e t h}$, according to the following expression [13]:

$$
\left(\delta^{13} \mathrm{C}_{\text {-OM }}\right) \times(1)=(0.5) \times\left(\delta^{13} \mathrm{C}-\mathrm{CH}_{4}\right)+(0.5) \times\left(\delta^{13} \mathrm{C}-\mathrm{CO}_{2 \text {-meth }}\right)
$$

This approach does not discriminate between the fractionation derived from the reduction in $\mathrm{CO}_{2}$ and acetate fermentation since both methanogenic pathways produce an equimolar net amount of $\mathrm{CO}_{2}$ and $\mathrm{CH}_{4}$ [18] (see also [13] for a stoichiometry discussion of the methane production pathways). In our study, the DIC measured in the pore water $\left(\delta^{13} \mathrm{C}-\mathrm{CO}_{2}\right.$-pore) represents the $\Sigma \mathrm{CO}_{2}$ of $(1)$ respiration and fermentation of the $\mathrm{OM}\left(\delta^{13} \mathrm{C}\right.$ $\left.\mathrm{CO}_{2}-\mathrm{OM}\right)$ with an isotopic signature similar to the $\mathrm{OM}$, (2) the methane production $\left(\delta^{13} \mathrm{C}\right.$ $\left.\mathrm{CO}_{2}-\mathrm{MP}\right)$, enriched with respect to $\mathrm{OM}$, and (3) $\mathrm{CO}_{2}$ from the $\mathrm{AOM}\left(\delta^{13} \mathrm{C}-\mathrm{CO}_{2}-\mathrm{AOM}\right)$. Thus, when the mangrove soil is continuously saturated with water, the isotope-mass balance can be determined from Equation (1) and from:

$$
\begin{aligned}
&\left(\delta^{13} \mathrm{C}-\mathrm{CO}_{2-\text { pore }}\right) \times(1)=\left(\delta^{13} \mathrm{C}-\mathrm{OM}\right) \times\left(\mathrm{f} \mathrm{CO}_{2-\mathrm{OM}}\right)+\left(\delta^{13} \mathrm{C}_{-} \mathrm{CO}_{2-\text { meth }}\right) \times\left(\mathrm{f} \mathrm{CO}_{2 \text {-meth }}\right) \\
&+\left(\delta^{13} \mathrm{C}-\mathrm{CO}_{2-\mathrm{AOM}}\right) \times\left(\mathrm{f} \mathrm{CO}_{2-\mathrm{AOM}}\right) \\
&\left(\mathrm{f} \mathrm{CO} \mathrm{CO}_{2-\mathrm{AOM}}\right)+\left(\mathrm{f} \mathrm{CO}_{2-\mathrm{OM}}\right)+\left(\mathrm{f} \mathrm{CO}_{2 \text {-meth }}\right)=1
\end{aligned}
$$

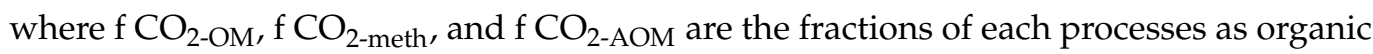
matter fermentation and respiration, methanogenesis, and AOM, respectively.

The mass balance equation determined the $\mathrm{f}_{2}$-meth:

$$
\text { (f } \begin{aligned}
\left.\mathrm{CO}_{2} \text {-meth }\right)=\left(\delta^{13} \mathrm{C}_{-} \mathrm{OM}\right) & -\left(\delta^{13} \mathrm{C}-\mathrm{CO}_{2-\text { pore }}\right)-\left(\delta^{13} \mathrm{C}_{-} \mathrm{CO}_{2-\mathrm{AOM}}\right) /\left(\delta^{13} \mathrm{C}-\mathrm{CO}_{2} \text {-meth }\right) \\
& -\left(\delta^{13} \mathrm{C}_{-} \mathrm{OM}\right)-\left(\delta^{13} \mathrm{C}-\mathrm{CO}_{2} \text {-pore }\right)
\end{aligned}
$$

Furthermore, finally, combining both equations $\mathrm{f} \mathrm{CO}_{2-\mathrm{OM}-\mathrm{AOM}-\mathrm{Other}}$ can be calculated:

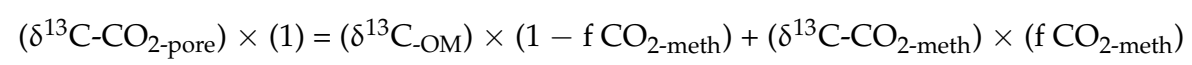

With the equimolar production of $\mathrm{CH}_{4}$ to $\mathrm{CO}_{2}$, we would expect to find the same amount of dissolved $\mathrm{CH}_{4}$ and $\mathrm{CO}_{2}$ from methanogenesis. Subtracting the measured 
$\left[\mathrm{CH}_{4}\right]_{\text {Meas }}$ from the produced $\left(\left[\mathrm{CH}_{4}\right]_{\text {Prod }}\right.$, based on $\left.\left[\mathrm{CO}_{2-\text { meth }}\right]\right)$, the concentration of $\mathrm{CH}_{4}$ that escaped from the pore water was estimated $\left[\mathrm{CH}_{4}\right]_{\mathrm{Fug}}$ :

$$
\left[\mathrm{CH}_{4}\right]_{\text {Prod }}-\left[\mathrm{CH}_{4}\right]_{\text {Meas }}=\left[\mathrm{CH}_{4}\right]_{\text {Fug }}
$$

AOM in coastal waters occurs linked to sulfate reduction according to:

$$
\mathrm{CH}_{4}+\mathrm{SO}_{4}{ }^{2-} \rightarrow \mathrm{HCO}_{3}{ }^{-}+\mathrm{HS}^{-}+\mathrm{H}_{2} \mathrm{O}
$$

When AOM occurs, the $\delta^{13} \mathrm{C}-\mathrm{CH}_{4}$ signature should be enriched, whereas the $\delta^{13} \mathrm{C}$ $-\mathrm{CO}_{2 \text {-pore }}$ should be depleted relative to the $\delta^{13} \mathrm{C}^{-} \mathrm{CH}_{4}$ source [41]. The fractionation factor for $\mathrm{AOM}(\alpha-\mathrm{AOM})$ has been estimated to be 1.012-1.039 in marine habitats by in vitro experiments [42]. In pore water field samples, the isotope mass balance could not differentiate those changes on $\delta^{13} \mathrm{C}$ signature in $\mathrm{CH}_{4}$ derived by AOM. Although in released $\delta^{13} \mathrm{C}_{-} \mathrm{CO}_{2-\mathrm{AOM}}$, a fractionation occurs during AOM (Equation (11); $\alpha-\mathrm{CH}_{4}-\mathrm{CO}_{2}=1.0088$ $\pm 0.0013 ;[43])$, and a fraction of it is recycled and consumed again in the system during methanogenesis, which is difficult to determine by the $\delta^{13} \mathrm{C}-\mathrm{CO}_{2}$-pore mass balance. Therefore, laboratory incubations were used to assess the fraction of $\mathrm{CH}_{4}$ lost by AOM from the $\mathrm{CH}_{4}$ escaped $\left(\left[\mathrm{CH}_{4}\right]_{\text {Fug }}\right)$. Because incubations represented closed systems, we assumed the $\left[\mathrm{CH}_{4}\right]_{\text {Fug }}=\left[\mathrm{CH}_{4}\right]_{\mathrm{AOM}}$, and the fraction of $\mathrm{CH}_{4}$ consumed by AOM could then be calculated

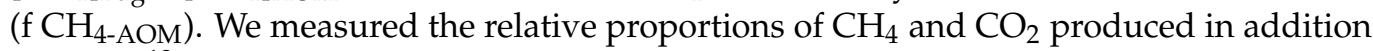
to their $\delta^{13} \mathrm{C}$ isotopic composition. These results were used to test against the proportions predicted from the isotope-mass balance approach.

\subsection{Sampling Procedure}

In February 2016, at each sampling station, three mini piezometers were installed in the mangrove soils (PVC tubes of $1.25 \mathrm{~cm}$ in diameter and $15 \mathrm{~cm}$ in length, covered at the top) separated by $2 \mathrm{~m}$ from each other, which were allowed to stabilize for 60 days after several tidal cycles. In April 2016, pore water was collected at the bottom $(\approx 14 \mathrm{~cm})$ of each mini piezometers with the help of a peristaltic pump with Teflon tubing. The redox potential (Eh) was measured with a Hach HQ40d multi-parameter sonde (ORP) in the mini piezometers at $2 \mathrm{~cm}$ intervals. Pore water samples for DIC measurements were previously filtered with Whatman grade GF/D glass microfiber prefilters $(2 \mu \mathrm{m})$ and GF/F $(0.7 \mu \mathrm{m})$ and then injected into $30 \mathrm{~mL}$ evacuated vials sealed with butyl rubber septa. Pore water samples for $\mathrm{CH}_{4}$ quantification were collected in $60 \mathrm{~mL}$ syringes and injected into $120 \mathrm{~mL}$ evacuated vials containing $0.5 \mathrm{~g} \mathrm{KOH}$. Immediately in the laboratory, DIC samples were acidified with $0.3 \mathrm{~mL}$ of $40 \% \mathrm{H}_{3} \mathrm{PO}_{4}$. All evacuated vials containing DIC and $\mathrm{CH}_{4}$ collected from minipiezometer pore waters were brought to atmospheric pressure with $\mathrm{He}$ then agitated to extract the dissolved gas from the water into the headspace, and, finally, the gas accumulated in the headspace was stored into $12 \mathrm{~mL}$ exetainers vials (Labco Ltd., Lampeter, UK) and shipped to the stable isotope lab for concentration and $\delta^{13} \mathrm{C}$ analyses (see below). Aliquots of each pore water sample were also analyzed for ammonium, nitrate, total nitrogen, total phosphorus, and sulfate concentrations following standard methods [44]. All the samples were kept cold $\left(<4^{\circ} \mathrm{C}\right)$ and in the dark during the field trip, until the gases were extracted and analyses performed.

Soil samples (10-15 cm depth, to match with sampled pore water depth) taken at each sampling point were used to perform anaerobic incubations in the laboratory to complement the observations made in the field (see above). For this purpose, slurries were prepared using $25 \mathrm{~mL}$ of each soil sample saturated with distilled water (1 sediment: 2 water, by volume), previously bubbled in $\mathrm{N}_{2}$. Sediment slurry $(75 \mathrm{~mL})$ was then introduced into $120 \mathrm{~mL}$ opaque vials with butyl rubber septa that were again purged with $\mathrm{N}_{2}$ for more than $5 \mathrm{~min}$ to eliminate oxygen and to ensure anaerobic conditions. Vials were stored at $<4^{\circ} \mathrm{C}$ for one week and then flushed with $\mathrm{N}_{2}$ a second time to ensure the anaerobic environment. Finally, samples were incubated by triplicate at $25^{\circ} \mathrm{C}$ for 7 days. At the end of the incubations, gas from the headspace of each vial was extracted into $12 \mathrm{~mL}$ exetainers 
and then shipped to stable isotope laboratory for concentration and $\delta^{13} \mathrm{C}$ analyses as described below. The slurry of each vial was dried $\left(105^{\circ} \mathrm{C}\right)$ to estimate the soil content on a dry mass basis. Gas concentration data were then divided by the obtained mass in dry weight to normalize the $\mathrm{CO}_{2}$ and $\mathrm{CH}_{4}$ production and consumption per soil gram.

The gas concentration and isotopic ratio were determined by direct injection in a ThermoScientific Delta V Plus mass spectrometer (Thermo Fisher Scientific, Waltham, ME, USA) with a GC combustion interface ThermoScientific GasBench system $\left(\mathrm{CO}_{2}\right)$ and ThermoScientific Precon concentration unit $\left(\mathrm{CH}_{4}\right)$ in the Stable Isotope Laboratory at the University of California-Davis (SIF-UC Davis). The gas concentrations in pore waters were calculated from the ratio between the volume of headspace and that of water and according to the efficiency of gas extraction (the mean extraction efficiency of $\mathrm{CH}_{4}$ resulted in $95 \%$ as measured with repeated extractions; the mean extraction efficiency of DIC was $99 \%$ as determined against standard solutions of $\mathrm{NaCO}_{3}$ ). For most gases, the heavier isotope has a higher solubility [45], and studies on $\mathrm{CH}_{4}$ confirmed the same results [46]. Since gases with higher solubility reach equilibrium between phases quicker [47], the rate of gas exchange for the heavier ${ }^{13} \mathrm{CH}_{4}$ isotope should be faster. However, dissolution is driven by two gradients: the solubility of $\mathrm{CH}_{4}$ in the water phase and the molecular diffusion of $\mathrm{CH}_{4}$ across the gas-liquid boundary. Molecular diffusion is faster for the lighter ${ }^{12} \mathrm{CH}_{4}$ isotope, potentially counterbalancing the solubility effect [48] and any unaccounted isotopic fractionation effect.

Mangrove soils were also analyzed to determine the $\delta^{13} \mathrm{C}_{-\mathrm{OM}}$ at the Environmental Isotope Laboratory of the University of Arizona, using a Finnigan Delta PlusXL (Thermo Fisher Scientific, Waltham, ME, USA) coupled to a Costech EA (Costech Analytical Tech Inc., Valencia, CA, USA). The isotopic data are described as $\delta(\%)=\left(R_{\text {sample }} / R_{\text {std }}-1\right) \times$ 1000 , where $R$ represents the isotopic ratio of the heavy isotope with the lighter isotope $\left({ }^{13} \mathrm{C} /{ }^{12} \mathrm{C}\right)$ and $\mathrm{R}_{\text {std }}$ refers to the fossil calcite of the Peedee formation belemnite.

\subsection{Isotopic Fractionation during Methanogenesis and Relative Contribution of Pathways}

The apparent fractionation factor for conversion of $\mathrm{CO}_{2}$ to $\mathrm{CH}_{4}$ was estimated after the laboratory incubations following:

$$
\alpha \mathrm{CO}_{2}-\mathrm{CH}_{4}=\left(\delta \mathrm{CO}_{2}+1000\right) /\left(\delta \mathrm{CH}_{4}+1000\right)
$$

where $\delta \mathrm{CO}_{2}$ and $\delta \mathrm{CH}_{4}$ are the $\delta^{13} \mathrm{C}$ signatures of the produced $\mathrm{CO}_{2}$ and $\mathrm{CH}_{4}$ after incubations. The isotopic signature of a newly formed $\mathrm{CH}_{4}\left(\delta^{13} \mathrm{C}-\mathrm{CH}_{4-n e w}\right)$ during methanogenesis was estimated from the isotopic signatures at the starting time ( $t=1$ or 0 days; $\left.\delta^{13} \mathrm{C}_{-} \mathrm{CH}_{4-1}\right)$ and after the anaerobic incubation $\left(t=2\right.$ or 7 days; $\left.\delta^{13} \mathrm{C}^{-} \mathrm{CH}_{4-2}\right)$ employing the mass balance equation [49]:

$$
\left(\delta^{13} \mathrm{C}_{-} \mathrm{CH}_{4-2}\right)=\left(\mathrm{f} \mathrm{CH}_{4-\text { new }}\right) \times\left(\delta^{13} \mathrm{C}_{-} \mathrm{CH}_{4-\text { new }}\right)+\left(1-\mathrm{f} \mathrm{CH}_{4-\text { new }}\right) \times\left(\delta^{13} \mathrm{C}_{-} \mathrm{CH}_{4-1}\right)
$$

where ( $\mathrm{CH}_{4}$-new) is the fraction of the newly formed $\mathrm{CH}_{4}$ relative to the total at $t=2$.

Finally, the relative contribution of $\mathrm{H}_{2}+\mathrm{CO}_{2}$-derived $\mathrm{CH}_{4}$ to total produced $\mathrm{CH}_{4}$ was determined by the mass balance equation:

$$
\text { (f } \left.\mathrm{CH}_{4-\mathrm{mc}}\right)=\left(\delta^{13} \mathrm{C}^{-\mathrm{CH}_{4-\text { new }}}\right)-\left(\delta^{13} \mathrm{C}-\mathrm{CH}_{4-\mathrm{ma}}\right) /\left(\delta^{13} \mathrm{C}-\mathrm{CH}_{4-\mathrm{mc}}-\delta^{13} \mathrm{C}-\mathrm{CH}_{4-\mathrm{ma}}\right)
$$

where $\mathrm{f} \mathrm{CH}_{4-\mathrm{mc}}$ is the fraction of $\mathrm{CH}_{4}$ formed from $\mathrm{H}_{2}+\mathrm{CO}_{2}$, and $\delta^{13} \mathrm{C}^{-} \mathrm{CH}_{4-\mathrm{ma}}$ and $\delta^{13} \mathrm{C}$ $\mathrm{CH}_{4-\mathrm{mc}}$ are the isotope ratios of $\mathrm{CH}_{4}$ derived from either acetate or $\mathrm{H}_{2}+\mathrm{CO}_{2}(-56 \%$ and $-95 \%$, respectively; [49]). The isotopic fractionation was also expressed as the isotopic enrichment factor $(\varepsilon \equiv 1000(\alpha-1))$.

\subsection{Mangrove Wetland Characterizations}

The structure of mangrove forests was obtained using equidistant $10 \mathrm{~m}^{2}$ quadrants around the experimental sites, following the criteria proposed by [50]. The average height, 
density, and basal area of mangrove trees were assessed following [51]. Soil samples $(0-10 \mathrm{~cm})$ taken at each sampling station were analyzed for total organic carbon and nitrogen using a Perkin Elmer (Series II 2400) elemental analyzer, total phosphorus by highperformance liquid chromatography (Agilent 1100 HPLC), salinity (electrical conductivity converted to ppm), bulk density (paraffin clod method; [52]), and grain size (Bouyoucos hydrometer method; [53]).

\subsection{Statistical Analyses}

ANOVA (using type III sum of squares for accounting for the unbalanced sampling design) was used to compare $\delta^{13} \mathrm{C}$ signatures and DIC and $\mathrm{CH}_{4}$ concentrations among sampling sites. Before this statistical analysis, data were log-transformed when necessary to fulfill the requirements of parametric tests. The non-parametric Spearman rank-order correlations were used to assess relationships between gas concentrations and nutrient concentration in the solid and liquid fractions of mangrove soils. Moreover, Spearman correlations were used to test the influence of soil fractions and nutrient pore waters on the methane produced by the isotope-mass balance approach with transformed data. The non-parametric Kruskal-Wallis ANOVA test was used to assess significant differences in $\mathrm{CH}_{4}$ and $\mathrm{CO}_{2}$ concentration changes and $\delta^{13} \mathrm{C}-\mathrm{CO}_{2}$ and $\delta^{13} \mathrm{C}-\mathrm{CH}_{4}$ changes after anaerobic incubations in each sampling point, including results obtained from the isotope-mass balances. All statistical analyses were performed using STATISTICA v7 (Statsoft Inc., Tulsa, OK, USA) and IBM SPSS Statistics 27.0 (IBM Corp., Armonk, NY, USA).

\section{Results}

\subsection{Mangrove Forest and Soil Properties}

Table 1 shows a summary of the main physical and chemical soil properties of mangrove stands at each sampling site and the structure of the mangrove forest stands. Although there is high variability, the stoichiometric ratio of $\mathrm{C} / \mathrm{N}$ ratio was slightly higher in pristine mangrove sites (ALG) than in MEL and DOM sites exposed to nutrient-enriched shrimp farm discharges. These last mangrove soils exhibited high phosphorus soil content. The redox potential varied from $-122.1 \pm 4.3 \mathrm{mV}$ at $2 \mathrm{~cm}$ of soil depth to $-171.4 \pm 4.9 \mathrm{mV}$ at $14 \mathrm{~cm}$ depth, with slight differences below $6 \mathrm{~cm}$ of soil depth $(-169.3 \pm 3.5 \mathrm{mV})$. No significant differences were found between mangrove sites and piezometers (non-parametric Kruskal-Wallis ANOVA test, $p=0.08$ ). Ammonium and total phosphorus contents in soil pore waters were strongly dictated by the distance to the shrimp farm effluent (Table 1). Total nitrogen concentration in pore water was higher in MEL sites. Sulfate in pore waters ranged from 25.1 to $29.1 \mathrm{mM}$, but a pattern exerted by the distance to the seawater and the effluents was inappreciable. The $\delta^{13} \mathrm{C}_{-} \mathrm{OM}$ of mangrove soils displayed signatures within the same range regardless of location, only with slightly enriched values recorded in the DOM-2 site (Table 1). Mangrove forest stands were better preserved in the ALG site, but, in the MEL and DOM sites, there was no clear effect on the proximity to the effluent discharges in the mangrove structural variables measured (Table 1). Tree density ranged from 900 to 4400 tree $\mathrm{ha}^{-1}$ in the marginal area of Estero Santo Domingo and the littoral zone of Estero Los Algodones, respectively, but, any effect of effluent discharge was not observed. The basal area of mangrove forest stands was strongly variable among sampling sites, with elevated values in Algodones. Neither did this variable seem affected by the proximity to the effluent discharges.

\subsection{Field Pore Water $\mathrm{CO}_{2}$ and $\mathrm{CH}_{4}$ Concentrations and $\delta^{13} \mathrm{C}$ Signatures}

DIC concentration in soil pore waters ranged from 0.44 to $2.47 \mathrm{mM}$ (Figure 2) and increased significantly in pristine mangrove forest (ANOVA test $p=0.01$ ), although differences are based in contrasted concentrations recorded in MEL-1, MEL-2, and MEL-3 with ALG-1 and ALG-2 (Tukey HSD post hoc $p<0.05$ ). $\mathrm{CH}_{4}$ concentration in pore waters oscillated between 0.03 and $0.55 \mu \mathrm{M}$, showing a uniform pattern: high concentrations in mangrove stands located far from the shoreline of the lagoons, regardless of whether or 
not there are shrimp farm effluents (Figure 2). $\mathrm{CO}_{2}$ concentration in soil pore waters was inversely related with phosphorus (with soil $\mathrm{P}$ content: Spearman rank-order correlation $r=-0.75, p=0.02$; with pore water total phosphorus: $r=-0.95, p=0.0001$ ) and nitrogen (pore water $\mathrm{NH}_{4}{ }^{+}: r=-0.72, p=0.3$ : pore water $\mathrm{NO}_{2}: r=-0.94, p=0.0002$; pore water total $\mathrm{N}: r=-0.73, p=0.03)$. Whereas the physical environment exerted a strong control on $\mathrm{CO}_{2}$ migration through the soil profile (relationship with sand (\%): $r=-0.84, p=0.005$; with silt (\%): $r=0.80, p=0.01$; and with clay (\%): $r=0.69, p=0.04)$, it was not observed with $\mathrm{CH}_{4}$. The phosphorus content in mangrove soils as well ammonium in pore waters revealed significant inverse relationships with $\mathrm{CH}_{4}$ concentration $(r=-0.70, p=0.03$ and $r=-0.67, p=0.05$, respectively). In impacted mangrove sites, $\mathrm{CO}_{2} / \mathrm{CH}_{4}$ ratios exhibited high values in sampling stations close to effluents (MEL-1 and DOM-1; Figure 2); in the pristine site ALG, $\mathrm{CO}_{2} / \mathrm{CH}_{4}$ ratios increased towards the coast (ALG-3 and ALG-4; Figure 2).

a)

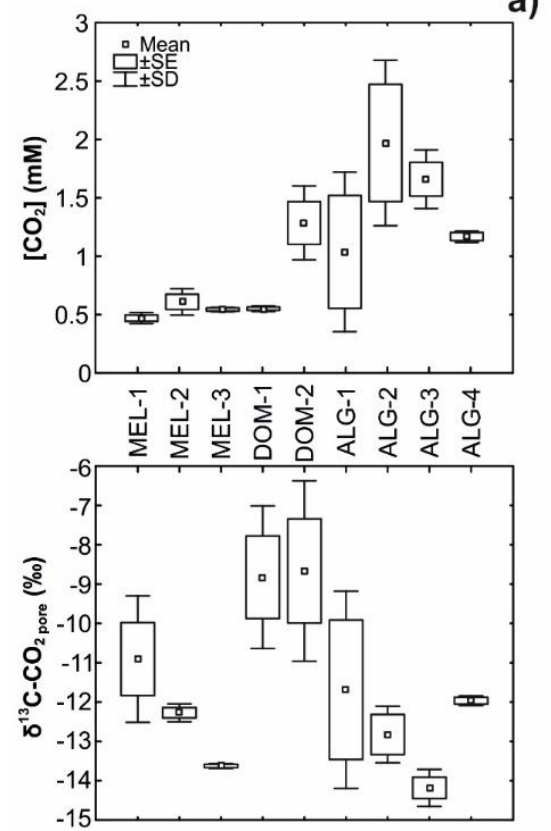

b)

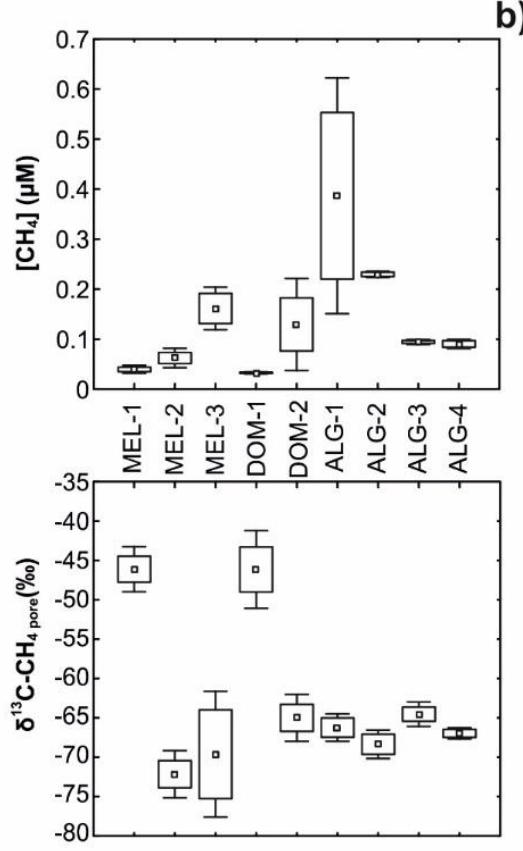

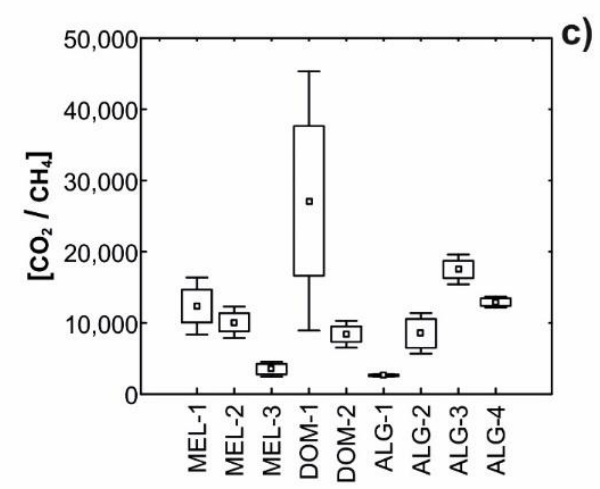

Figure 2. Concentration and $\delta^{13} \mathrm{C}$ signatures measured in pore waters extracted from mini piezometer in each sampling site for (a) $\mathrm{CO}_{2},(\mathbf{b}) \mathrm{CH}_{4}$, and (c) $\mathrm{CO}_{2} / \mathrm{CH}_{4}$ ratios.

The $\delta^{13} \mathrm{C}_{-}-\mathrm{CO}_{2 \text {-pore }}$ signatures were strongly variable among sampling sites, oscillating between -8.7 and $-14.2 \%$ o (Figure 2). The $\delta^{13} \mathrm{C}_{-} \mathrm{CH}_{4}$ values became more enriched in mangrove soils close to effluents ( $-46 \%$ in MEL- 1 and DOM-1) than the remaining sites (from -65 to $-72 \%$; Figure 2). Soil salinity and the $\delta^{13} \mathrm{C}_{-} \mathrm{CH}_{4}$ signatures were inversely related (Spearman rank-order correlation $r=-0.94, p=0.0002$ ). The $\delta^{13} \mathrm{C}_{-} \mathrm{CO}_{2}$-pore signatures and nitrate concentration exhibited a significant relationship $(r=0.73, p=0.03)$. 


\subsection{Laboratory Incubations}

During anaerobic incubations, $\mathrm{CO}_{2}$ concentration increased in all samples 1-0 fold with a more even response in impacted sites (Figure 3). Changes in $\mathrm{CO}_{2}$ concentrations reached after incubations were not statistically significant (Kruskal-Wallis ANOVA test, $p=0.06)$. $\mathrm{CH}_{4}$ concentrations increased more than 100 times during laboratory incubations, with higher values and high variability among replicates in the most pristine site ALG samples. These final $\mathrm{CH}_{4}$ concentrations and the changes recorded in $\mathrm{CH}_{4}$ concentrations after incubations were statistically significant $(p=0.13$ and $p=0.14$, respectively.
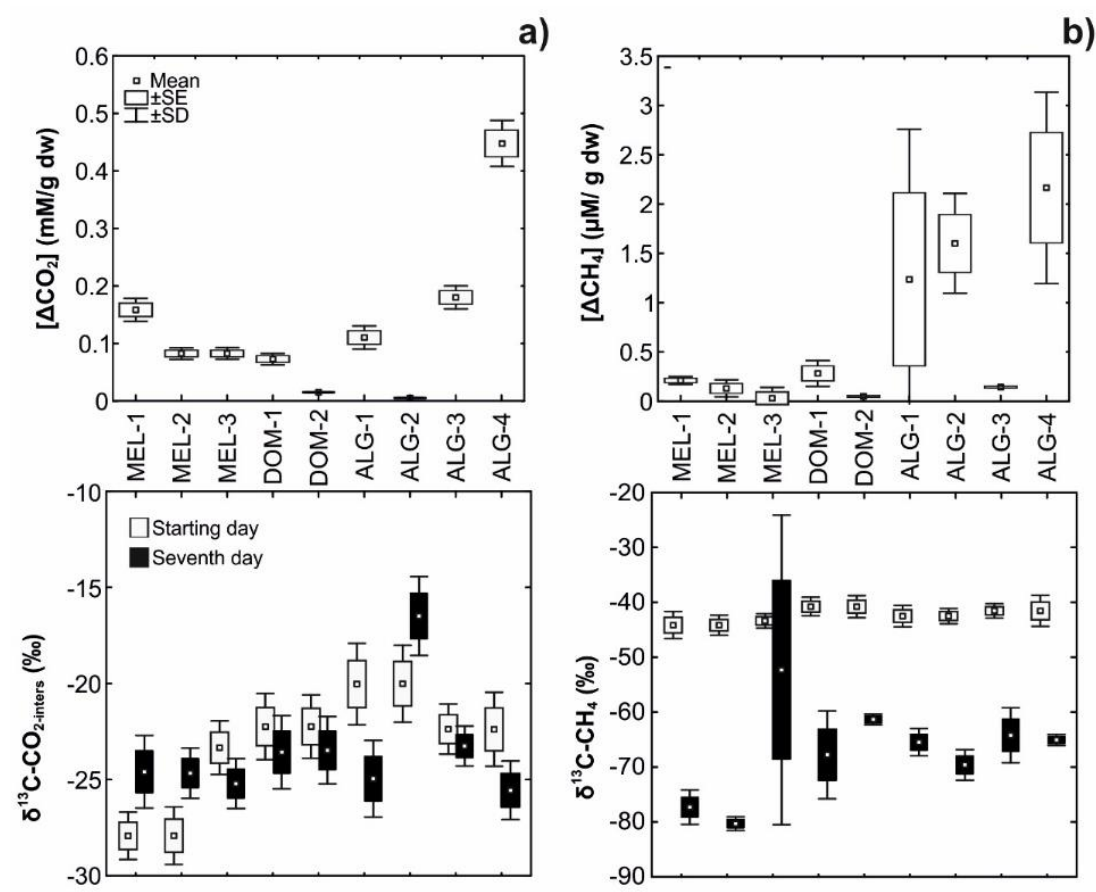

Figure 3. Changes in concentration (per gram of dry weight $(\mathrm{dw})$ of soil) and $\delta^{13 C}$ signatures measured in mangrove soil samples after seven days of closed-system incubations under anaerobic conditions: (a) $\mathrm{CO}_{2}$ and (b) $\mathrm{CH}_{4}$.

Starting $\mathrm{CO}_{2} / \mathrm{CH}_{4}$ ratios in pore waters were significantly lower in ALG $(p=0.0004)$, although they were similar to DOM $(p=0.20)$. $\mathrm{CO}_{2} / \mathrm{CH}_{4}$ ratios decreased consistently, mainly in ALG pristine sites: 1-91 times $(p=0.05)$. In MEL-3 and ALG-3 soil samples, which apparently were more influenced by seawater, $\mathrm{CO}_{2} / \mathrm{CH}_{4}$ ratios increased after incubations, but differences were not significant $(p>0.1)$. The starting values of $\delta^{13} \mathrm{C}$ $\mathrm{CO}_{2 \text {-pore }}$ were significantly different between mangrove sampling sites (Figure 3). After seven days of incubation, ${ }^{13} \mathrm{C}^{-} \mathrm{CO}_{2}$-pore became enriched in MEL sites closed to shrimp-farm discharges, whereas in the other DOM and ALG sites, $\delta^{13} \mathrm{C}_{-} \mathrm{CO}_{2 \text {-pore }}$ was depleted, except in the ALG-2 site (Figure 3). However, the final $\delta^{13} \mathrm{C}-\mathrm{CO}_{2}$-pore signatures reached were not statistically different $(p=0.11)$. MEL samples—dictated by MEL-1 and MEL-2-also displayed significantly lower initial $\delta^{13} \mathrm{C}-\mathrm{CH}_{4-\text { pore }}$ signatures $(p=0.03)$. After incubations, on average, $\delta^{13} \mathrm{C}-\mathrm{CH}_{4-p o r e}$ signatures were depleted (Figure 3). Therefore, after incubations, differences in $\delta^{13} \mathrm{C}_{-} \mathrm{CH}_{4-\text { pore }}$ signatures were removed between sites $(p=0.19)$.

\subsection{Isotope Mass Balances}

The $\delta^{13} \mathrm{C}-\mathrm{CO}_{2}$ mass balances calculated for field observations and laboratory incubations are shown in Table 2. In the first batch of samples, mean $\delta^{13} \mathrm{C}$ stable isotope signature separation between $\delta^{13} \mathrm{C}-\mathrm{CH}_{4}$ and $\delta^{13} \mathrm{C}^{-} \mathrm{CO}_{2 \text {-meth }}$ ranged from -57.03 to -84.44 , with high values in MEL (except MEL-1) and low values in DOM. In MEL-1, the mangrove site close to shrimp farm effluent, (f- $\mathrm{CO}_{2 \text {-meth }}$ ) was greater than in the other MEL sites 
(0.67 vs. $0.26-0.27)$. The estimated ( $\mathrm{f}-\mathrm{CO}_{2-\text { meth }}$ ) in ALG was very similar to these last sampling points and 10-20\% higher in DOM sites. In all sampling sites, except MEL-1, the fraction of $\mathrm{CO}_{2}$ derived from other sources (OM, AOM, and other non-fractionating) was consistently higher. Contrarily, the laboratory incubations exhibited a large fraction of $\mathrm{CO}_{2}$ derived from methanogenesis with slight differences among sampled mangroves.

Although the isotopic mass balance from pore waters obtained in field observations indicated that $\left[\mathrm{CH}_{4}\right]$ produced in DOM and ALG mangrove soils were significantly higher than in MEL sites (non-parametric Kruskal-Wallis ANOVA test, $p=0.017$ ), results from laboratory incubations did not display statistically significant differences ( $p=0.09$; Figure 4$)$. The $\delta^{13} \mathrm{C}-\mathrm{CO}_{2}$ mass balances also indicated that neither the distance to the effluents nor the sea exerted a significant influence on $\left[\mathrm{CH}_{4}\right]$ production differences in both lab incubations $(p=0.10, p=0.12$, and $p=0.08$, in MEL, DOM, and ALG, respectively; Figure 4) and field observations ( $p=0.06, p=0.13$, and $p=0.18$, in MEL, DOM, and ALG, respectively; Figure 4). Isotopic mass balances showed that almost all the $\left[\mathrm{CH}_{4}\right]_{\text {prod }}$ escaped (field) or was consumed by AOM (f $\mathrm{CH}_{4-\mathrm{AOM}}$ in lab incubations), except in ALG-2 incubated soil samples (Table 2).

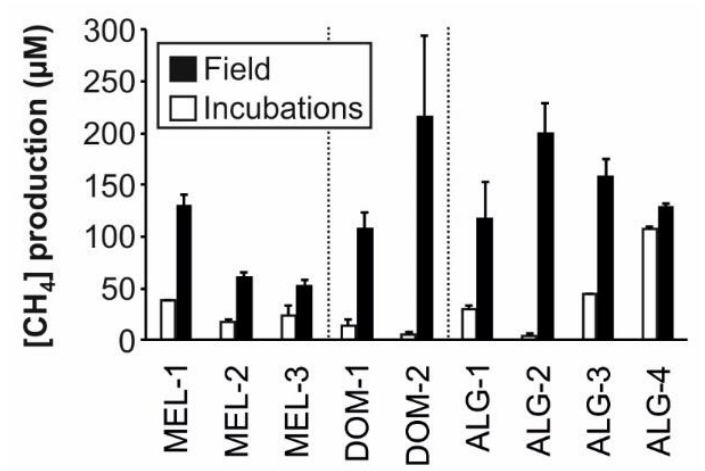

Figure 4. Estimated total $\mathrm{CH}_{4}$ produced through isotopic $\left(\delta^{13} \mathrm{C}\right)$ mass balances in each mangrove sampling site (mean $\pm \mathrm{SE}$ ). Data was obtained from 7-day closed-system laboratory incubations using mangrove soils (incubations; $\mu \mathrm{M} / \mathrm{g} \mathrm{dw}$ ) and from pore waters extracted from mini piezometers during the field campaign.

Comparatively, the relative portions of $\mathrm{CO}_{2}\left(\mathrm{f}-\mathrm{CO}_{2}\right.$-meth $)$ derived from methanogenesis calculated through the isotopic mass balance were greater than those obtained by the concentrations (f-CO $-\mathrm{CO}_{2-\text { meth }}=\left[\mathrm{CH}_{4}\right] /\left[\mathrm{CO}_{2}\right]$ ), both in the laboratory incubations and in the pore water collected from the mini piezometers (Figure 5). The calculated portions $\mathrm{f}-\mathrm{CO}_{2 \text {-meth }}$ did not exhibit any pattern (Figure 5). In the $\mathrm{f}-\mathrm{CO}_{2 \text {-meth }}$ obtained directly in the pore water field samples, a bias could be appreciated, displaying an evident linear pattern, with minor differences in the portions obtained by both approaches in the ALG sampling sites and very uneven differences in the MEL sites (DOM occupied an intermediate position; Figure 5).

The isotopic fractionation produced in methanogenesis $\left(\alpha \mathrm{CO}_{2}-\mathrm{CH}_{4}\right)$ during anaerobic incubations was, on average, $1.027(27 \pm 11 \%)$ and was slightly variable among sites (Table 3). On the contrary, the results from the isotopic mass balance demonstrated that

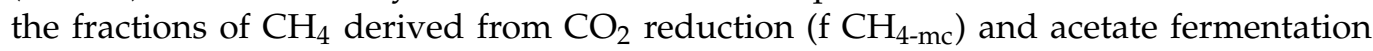
( $\mathrm{f} \mathrm{CH}_{4-m a}$ ) were highly different between the studied mangroves: they were more linked to the reduction in $\mathrm{CO}_{2}$ in the most-impacted mangrove site MEL, with a higher fraction the closer to the shrimp effluent (MEL-1, MEL-2, and DOM-1; Table 3). On the other hand, a higher fraction of methane was derived by the acetoclastic pathway in the remaining ALG (Table 3). 


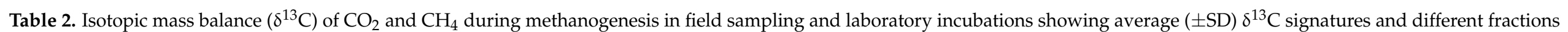

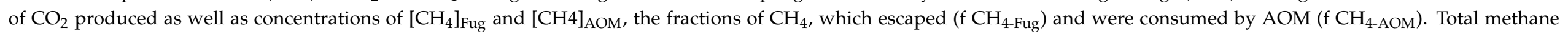
production in mangrove sites is also shown in $\mathrm{CO}_{2-\mathrm{eq}}\left(\mathrm{CO}_{2}+\mathrm{CH}_{4}\right.$ produced during the process).

\begin{tabular}{|c|c|c|c|c|c|c|c|c|c|}
\hline & MEL-1 & MEL-2 & MEL-3 & DOM-1 & DOM-2 & ALG-1 & ALG-2 & ALG-3 & ALG-4 \\
\hline \multicolumn{10}{|l|}{ Field measurements: } \\
\hline$\delta^{13} \mathrm{C}-\mathrm{OM}(\%)$ & $-25.1 \pm 0.02$ & $-25.1 \pm 0.03$ & $-25 \pm 0.03$ & $-23.3 \pm 0.04$ & $-23.1 \pm 0.09$ & $-25.1 \pm 0.02$ & $-25.1 \pm 0.01$ & $-24.6 \pm 0.05$ & $-24.7 \pm 0.13$ \\
\hline$\delta^{13} \mathrm{C}_{-} \mathrm{CH}_{4}(\%)$ & $-46.1 \pm 2.86$ & $-72.2 \pm 3.00$ & $-69.6 \pm 7.98$ & $-53.4 \pm 7.56$ & $-57.8 \pm 15.1$ & $-66.2 \pm 1.74$ & $-68.4 \pm 1.81$ & $-64.5 \pm 1.55$ & $-67 \pm 0.71$ \\
\hline$\delta^{13} \mathrm{C}-\mathrm{CO}_{2 \text {-pore water }}(\%$ o $)$ & $-10.9 \pm 1.61$ & $-12.3 \pm 0.23$ & $-13.6 \pm 0.06$ & $-7.9 \pm 0.31$ & $-9.6 \pm 2.55$ & $-11.7 \pm 2.51$ & $-12.8 \pm 0.72$ & $-14.2 \pm 0.47$ & $-12 \pm 0.12$ \\
\hline$\left(\delta^{13} \mathrm{C}-\mathrm{CO}_{2-\text { meth }}\right)$ & $-4 \pm 2.87$ & $22 \pm 3.05$ & $19.5 \pm 7.92$ & $6.9 \pm 7.64$ & $11.7 \pm 15.12$ & $16 \pm 1.69$ & $18.3 \pm 1.82$ & $15.3 \pm 1.48$ & $17.6 \pm 0.45$ \\
\hline (f $\mathrm{CO}_{2 \text {-meth }}$ ) & $0.67 \pm 0.13$ & $0.27 \pm 0.02$ & $0.26 \pm 0.05$ & $0.53 \pm 0.13$ & $0.45 \pm 0.22$ & $0.33 \pm 0.05$ & $0.28 \pm 0.03$ & $0.26 \pm 0.02$ & $0.3 \pm 0.001$ \\
\hline (f $\mathrm{CO}_{2-\mathrm{OM}+\mathrm{AOM}+\text { other }}$ ) & $0.24 \pm 0.13$ & $0.73 \pm 0.02$ & $0.74 \pm 0.05$ & $0.47 \pm 0.13$ & $0.55 \pm 0.22$ & $0.67 \pm 0.05$ & $0.72 \pm 0.03$ & $0.74 \pm 0.02$ & $0.7 \pm 0.001$ \\
\hline$\left[\mathrm{CH}_{4}\right]_{\text {Prod }}(\mu \mathrm{M})$ & $129.9 \pm 18.97$ & $60.06 \pm 9.37$ & $51.65 \pm 11.15$ & $106.88 \pm 28.76$ & $215.17 \pm 135.88$ & $116.68 \pm 62.62$ & $199.03 \pm 52.5$ & $157.8 \pm 29.11$ & $127.76 \pm 6.16$ \\
\hline$\left[\mathrm{CH}_{4}\right]_{\text {Fug }}(\mu \mathrm{M})$ & $129.86 \pm 18.97$ & $59.99 \pm 9.35$ & $51.49 \pm 11.2$ & $106.84 \pm 28.77$ & $215.05 \pm 135.95$ & $116.29 \pm 62.39$ & $198.8 \pm 52.5$ & $157.71 \pm 29.11$ & $127.66 \pm 6.15$ \\
\hline (f $\left.\mathrm{CH}_{4-\mathrm{Fug}}\right)$ & 1 & 1 & 1 & 1 & 1 & 1 & 1 & 1 & 1 \\
\hline Methanog. $\left[\mathrm{CO}_{2-\mathrm{eq}}(\mathrm{mM})\right]$ & $3.6 \pm 0.53$ & $1.67 \pm 0.26$ & $1.43 \pm 0.31$ & $2.97 \pm 0.8$ & $5.97 \pm 3.77$ & $3.24 \pm 1.74$ & $5.52 \pm 1.46$ & $4.38 \pm 0.81$ & $3.55 \pm 0.17$ \\
\hline \multicolumn{10}{|l|}{ Laboratory incubations: } \\
\hline$\delta^{13} \mathrm{C}-\mathrm{OM}(\%$ ) & $-25.1 \pm 0.03$ & $-25.1 \pm 0.04$ & $-25.0 \pm 0.03$ & $-23.3 \pm 0.06$ & $-23 \pm 0.08$ & $-25.1 \pm 0.02$ & $-25.1 \pm 0$ & $-24.6 \pm 0.06$ & $-24.7 \pm 0.13$ \\
\hline$\delta^{13} \mathrm{C}_{-} \mathrm{CH}_{4}(\%)$ & $-77.4 \pm 3.13$ & $-80.4 \pm 1.27$ & $-72.3 \pm 28.26$ & $-67.8 \pm 8.03$ & $-61.3 \pm 0.99$ & $-66.5 \pm 1.41$ & $-69.2 \pm 0.71$ & $-64.2 \pm 5.03$ & $-65.1 \pm 1.03$ \\
\hline$\delta^{13} \mathrm{C}-\mathrm{CO}_{2 \text {-pore water }}(\%$ o $)$ & $-24.5 \pm 0.14$ & $-24.7 \pm 0.03$ & $-25.7 \pm 0.64$ & $-23.5 \pm 0.12$ & $-23.6 \pm 0.1$ & $-25 \pm 0.02$ & $-18.3 \pm 2.59$ & $-22.9 \pm 0.51$ & $-25.7 \pm 0.12$ \\
\hline$\left(\delta^{13} \mathrm{C}-\mathrm{CO}_{2-\text { meth }}\right)$ & $27.3 \pm 3.18$ & $30.2 \pm 1.19$ & $22.2 \pm 28.32$ & $21.3 \pm 7.91$ & $15.3 \pm 0.82$ & $16.3 \pm 1.37$ & $19 \pm 0.71$ & $15.1 \pm 5.16$ & $15.7 \pm 1.29$ \\
\hline (f $\mathrm{CO}_{2 \text {-rest }}$ ) & $0.35 \pm 0.01$ & $0.35 \pm 0.001$ & $0.34 \pm 0.14$ & $0.34 \pm 0.02$ & $0.32 \pm 0.001$ & $0.32 \pm 0.001$ & $0.28 \pm 0.02$ & $0.31 \pm 0.02$ & $0.33 \pm 0.001$ \\
\hline$\left[\mathrm{CH}_{4}\right]_{\text {Prod }}(\mu \mathrm{M})$ & $37.76 \pm 0.44$ & $17.56 \pm 2.77$ & $23.23 \pm 10.69$ & $13.39 \pm 6.42$ & $5.41 \pm 2.23$ & $29.84 \pm 3.51$ & $3.64 \pm 3.13$ & $43.93 \pm 0.87$ & $107.17 \pm 2.11$ \\
\hline$\left[\mathrm{CH}_{4}\right]_{\text {Meas }}(\mu \mathrm{M})$ & $0.21 \pm 0.02$ & $0.13 \pm 0.03$ & $0.03 \pm 0.04$ & $0.28 \pm 0.12$ & $0.05 \pm 0.01$ & $1.24 \pm 0.76$ & $1.6 \pm 0.31$ & $0.15 \pm 0.02$ & $2.16 \pm 1.24$ \\
\hline$\left[\mathrm{CH}_{4}\right]_{\mathrm{AOM}}(\mu \mathrm{M})$ & $37.54 \pm 0.43$ & $17.42 \pm 2.8$ & $23.2 \pm 10.73$ & $13.1 \pm 6.55$ & $5.36 \pm 2.22$ & $28.6 \pm 2.75$ & $2.04 \pm 3.44$ & $43.79 \pm 0.85$ & $105.01 \pm 3.35$ \\
\hline$\left(\mathrm{f} \mathrm{CH}_{4-\mathrm{AOM}}\right)$ & $0.99 \pm 0.001$ & $0.99 \pm 0.001$ & $1 \pm 0.001$ & $0.97 \pm 0.02$ & $0.99 \pm 0.001$ & $0.96 \pm 0.02$ & $0.24 \pm 0.74$ & $1 \pm 0.001$ & $0.98 \pm 0.01$ \\
\hline Methanog. $\left[\mathrm{CO}_{2-\mathrm{eq}}(\mathrm{mM})\right]$ & $1.39 \pm 0.02$ & $0.65 \pm 0.1$ & $0.85 \pm 0.39$ & $0.49 \pm 0.24$ & $0.2 \pm 0.08$ & $1.1 \pm 0.13$ & $0.13 \pm 0.12$ & $1.61 \pm 0.03$ & $3.94 \pm 0.08$ \\
\hline
\end{tabular}




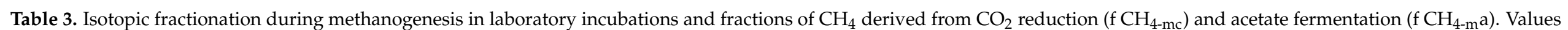
are averages $( \pm \mathrm{SD})$.

\begin{tabular}{|c|c|c|c|c|c|c|c|}
\hline & $\delta^{13} \mathrm{C}-\mathrm{OM}$ & $\begin{array}{c}\delta^{13} \mathrm{C}-\mathrm{CH}_{4-\text { pore }} \\
(\%)\end{array}$ & $\delta^{13} \mathrm{C}-\mathrm{CH}_{4-\text { new }}$ & $(-)$ & $(\%)$ & $\begin{array}{c}\left(\mathbf{f} \mathrm{CH}_{4-\mathrm{mc}}\right) \\
(-)\end{array}$ & $\begin{array}{c}\left(\mathrm{f} \mathrm{CH}_{4-\mathrm{ma}}\right) \\
(-)\end{array}$ \\
\hline MEL-1 & $-25.1 \pm 0.03$ & $-77.4 \pm 3.13$ & $-80.21 \pm 3.6$ & 1.036 & $(-36 \pm 4)$ & $0.62 \pm 0.09$ & $0.38 \pm 0.91$ \\
\hline MEL-2 & $-25.1 \pm 0.04$ & $-80.4 \pm 1.27$ & $-85.45 \pm 0.15$ & 1.039 & $(-39 \pm 1)$ & $0.76 \pm 0$ & $0.24 \pm 1$ \\
\hline Mean & $-25.06 \pm 0.004$ & $-76.68 \pm 3.96$ & $-80.24 \pm 5.22$ & 1.028 & $(-28 \pm 20)$ & $0.62 \pm 0.13$ & $0.38 \pm 0.13$ \\
\hline DOM-1 & $-23.3 \pm 0.06$ & $-67.8 \pm 8.03$ & $-69.4 \pm 7.78$ & 1.029 & $(-29 \pm 9)$ & $0.34 \pm 0.2$ & $0.66 \pm 0.8$ \\
\hline DOM-2 & $-23 \pm 0.08$ & $-61.3 \pm 0.99$ & $-63.65 \pm 1.34$ & 1.022 & $(-22 \pm 1)$ & $0.2 \pm 0.03$ & $0.8 \pm 0.97$ \\
\hline Mean & $-23.14 \pm 0.007$ & $-64.58 \pm 5.98$ & $-66.52 \pm 5.64$ & 1.026 & $(-26 \pm 7)$ & $0.27 \pm 0.14$ & $0.92 \pm 0.03$ \\
\hline ALG-1 & $-25.1 \pm 0.02$ & $-66.5 \pm 1.41$ & $-66.79 \pm 1.26$ & 1.026 & $(-26 \pm 2)$ & $0.28 \pm 0.03$ & $0.72 \pm 0.97$ \\
\hline ALG-2 & $-25.1 \pm 0$ & $-69.2 \pm 0.71$ & $-69.39 \pm 0.76$ & 1.029 & $(-29 \pm 1)$ & $0.34 \pm 0.02$ & $0.66 \pm 0.98$ \\
\hline ALG-3 & $-24.6 \pm 0.06$ & $-64.2 \pm 5.03$ & $-69.8 \pm 5.42$ & 1.024 & $(-24 \pm 6)$ & $0.35 \pm 0.14$ & $0.65 \pm 0.86$ \\
\hline ALG-4 & $-24.7 \pm 0.13$ & $-65.1 \pm 1.03$ & $-65.56 \pm 1.31$ & 1.025 & $(-25 \pm 1)$ & $0.25 \pm 0.03$ & $0.75 \pm 0.97$ \\
\hline Mean & $-24.86 \pm 0.003$ & $-66.25 \pm 2.84$ & $-67.89 \pm 2.89$ & 1.026 & $(-26 \pm 3)$ & $0.3 \pm 0.07$ & $0.7 \pm 0.07$ \\
\hline Overall mean & $-24.54 \pm 0.8$ & $-69.36 \pm 6.56$ & $-71.7 \pm 7.48$ & 1.027 & $(-27 \pm 11)$ & $0.4 \pm 0.19$ & $0.6 \pm 0.19$ \\
\hline
\end{tabular}


Incubations

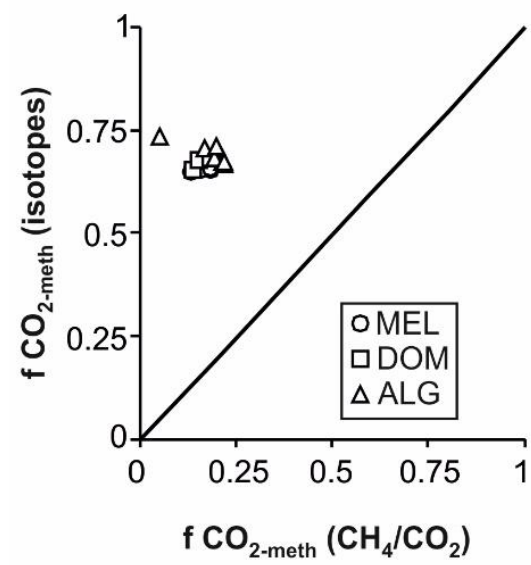

Field

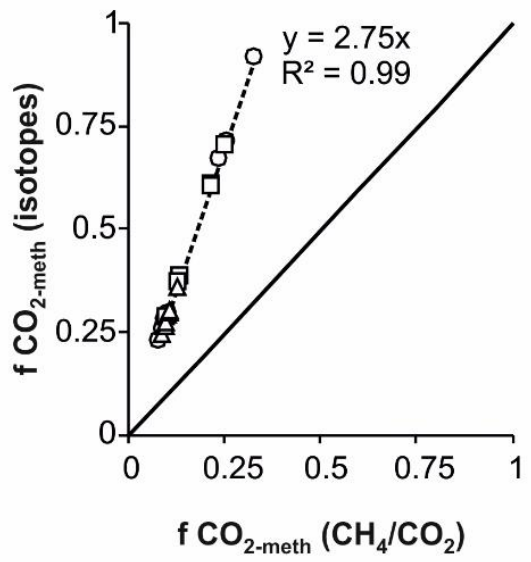

Figure 5. Plots showing the relationships between the fraction of $\mathrm{CO}_{2}$ produced from methanogenesis (f $\mathrm{CO}_{2 \text {-meth }}$ ) estimated by the isotope mass balances (isotopes) and by concentration measurements (stoichiometric ratio of $\mathrm{CH}_{4} / \mathrm{CO}_{2}$ ) in both the closed-system incubations (Incubations) and the pore waters extracted in the mini piezometers during the field campaign (Field). The solid line represents 1:1 relationship.

\subsection{Tidal, Forest Structure, and Water Quality Influences on Methane Production}

Table 4 shows correlations between the fraction of $\mathrm{CO}_{2}$ derived from methanogenesis (f- $\mathrm{CO}_{2}$-meth), the computed $\mathrm{CH}_{4}$ production ( $\left[\mathrm{CH}_{4}\right]_{\text {prod }}$ ) from the isotope-mass balances in both field and laboratory incubations, and the measured soil and pore water variables. $\mathrm{f}-\mathrm{CO}_{2}$-meth was more responsive than $\left[\mathrm{CH}_{4}\right]_{\text {prod }}$ to changes in soil and water quality variables in both batches of samples. In the field samples, the influence of water quality in the $\mathrm{f}-\mathrm{CO}_{2 \text {-meth }}$ of pore waters collected from the mini piezometers was restricted to salinity and sulfate concentration, which tend to limit methanogenesis. Methane production, however, showed a significant inverse relationship with tot- $\mathrm{N}$ content. In the lab incubations, relationships indicated a substantial limitation of methanogenesis with nutrient enrichment (inverse relationships between $\mathrm{f}-\mathrm{CO}_{2}$-meth and soil total phosphorus and pore water content of organic matter, ammonium, nitrite, and total-P). In addition, the direct effect exerted by the smallest soil grain sizes in methanogenesis revealed the importance of the water retention time (Table 4). Finally, the studied mangrove forests' basal area showed an inverse statistically significant correlation with $\mathrm{f}-\mathrm{CO}_{2}$-meth measured in field pore water samples.

Table 4. Spearman rank-order correlations ( $\mathrm{r}$ ) between the fraction of $\mathrm{CO}_{2}$ derived from methanogenesis and the total $\mathrm{CH}_{4}$ production calculated from isotope-mass balances in both field and laboratory incubation samples and measured soil and pore water variables. Marked correlations (bold) were significant at $p<0.05$.

\begin{tabular}{|c|c|c|c|c|}
\hline & \multicolumn{2}{|c|}{ Field } & \multicolumn{2}{|c|}{ Incubations } \\
\hline & (f CO 2 -meth) & {$\left[\mathrm{CH}_{4}\right]_{\text {prod }}(\mu \mathrm{M})$} & (f CO 2 -meth $)$ & {$\left[\mathrm{CH}_{4}\right]_{\text {prod }}(\mu \mathrm{M})$} \\
\hline \multicolumn{5}{|l|}{ Tidal and forest drivers: } \\
\hline Tidal freq. (tides $\mathrm{d}^{-1}$ ) & -0.06 & 0.62 & -0.40 & -0.49 \\
\hline Basal area $\left(\mathrm{m}^{2} \mathrm{ha}^{-1}\right)$ & -0.77 & 0.04 & -0.34 & 0.43 \\
\hline Tree density (tree ha ${ }^{-1}$ ) & -0.53 & -0.14 & -0.16 & 0.46 \\
\hline \multicolumn{5}{|l|}{ Soil fraction: } \\
\hline Bulk density $\left(\mathrm{g} / \mathrm{cm}^{3}\right)$ & 0.31 & -0.14 & -0.45 & -0.37 \\
\hline Total organic carbon (\%) & 0.17 & -0.10 & 0.27 & -0.14 \\
\hline Total nitrogen $(\%)$ & 0.22 & -0.17 & -0.22 & 0.00 \\
\hline Total phosphorus (\%) & 0.07 & -0.64 & -0.80 & 0.23 \\
\hline Sand $(\%)$ & 0.05 & -0.56 & -0.86 & -0.20 \\
\hline Silt (\%) & -0.48 & 0.52 & 0.78 & 0.23 \\
\hline Clay $(\%)$ & 0.23 & 0.33 & 0.69 & -0.09 \\
\hline
\end{tabular}


Table 4. Cont

\begin{tabular}{|c|c|c|c|c|}
\hline & \multicolumn{2}{|c|}{ Field } & \multicolumn{2}{|c|}{ Incubations } \\
\hline & (f CO 2 -meth) & {$\left[\mathrm{CH}_{4}\right]_{\text {prod }}(\mu \mathrm{M})$} & (f $\mathrm{CO}_{2 \text {-meth }}$ ) & {$\left[\mathrm{CH}_{4}\right]_{\text {prod }}(\mu \mathrm{M})$} \\
\hline \multicolumn{5}{|l|}{ Porewater fraction: } \\
\hline Salinity $(\mathrm{mg} / \mathrm{L})$ & -0.67 & -0.29 & -0.08 & -0.07 \\
\hline Total solids (mg/L) & 0.11 & -0.48 & -0.60 & -0.48 \\
\hline Total organic matter (mg/L) & 0.26 & -0.38 & -0.67 & -0.47 \\
\hline Total inorganic matter $(\mathrm{mg} / \mathrm{L})$ & -0.33 & 0.22 & 0.48 & -0.07 \\
\hline $\mathrm{N}^{-\mathrm{NO}_{2}}{ }^{-}(\mathrm{mg} \mathrm{N} / \mathrm{L})$ & 0.26 & -0.39 & -0.90 & 0.07 \\
\hline $\mathrm{N}-\mathrm{NH}_{4}{ }^{+}(\mathrm{mg} \mathrm{N} / \mathrm{L})$ & 0.01 & -0.60 & -0.85 & 0.28 \\
\hline $\mathrm{N}-\mathrm{NO}_{3}-(\mathrm{mg} \mathrm{N} / \mathrm{L})$ & 0.50 & 0.27 & 0.03 & -0.52 \\
\hline Tot-N (mg N/L) & -0.13 & -0.68 & -0.64 & 0.27 \\
\hline Tot-P (mg P/L) & 0.25 & -0.46 & -0.78 & -0.18 \\
\hline $\mathrm{SO}_{4}^{2-}(\mathrm{mM})$ & -0.73 & -0.13 & 0.08 & 0.62 \\
\hline
\end{tabular}

\section{Discussion}

\subsection{Validity of the Isotope-Mass Balance Approach to Estimate Methane Production in Mangroves}

This study is the first to estimate methane production in mangrove wetlands using the isotope-mass balance approach to assess the partition $\mathrm{CO}_{2}$ (DIC) production from fractionating (methanogenesis) and non-fractionating processes. The isotopic fractionation that occurs during methanogenesis in mangrove soils resulted very evidently (isotopic separation factor during incubations $\approx-43 \pm 11 \%$ ), and this allows an easy distinction of the isotopic signatures derived from non-fractional metabolic processes. The $\delta^{13} \mathrm{C}-\mathrm{CO}_{2}$ isotope mass balances demonstrated that $\mathrm{CH}_{4}$ production predominantly occurs in mangroves, as other studies have previously shown (e.g., [13,54]). The anaerobic and organic-rich sediments found in these systems provide a suitable environment for methanogenesis, yet the extensive supply of sulfate from seawater should favor sulfate reducers over methanogens in the shallow sections of the mangrove soils [14]. Our isotope-mass balances indicated that the low concentration of $\mathrm{CH}_{4}$ measured in mangrove soil pore waters was due to $\mathrm{CH}_{4}$ oxidation under anaerobic conditions (AOM) instead of methane inhibition by sulfate reducers, which outcompete methanogens for common substrates [55].

The agreement between measured portioning of DIC and the calculated isotope-mass balances was rather low, mainly in the laboratory incubations. Differences observed were probably associated with the effects of $\mathrm{AOM}$ on the $\delta^{13} \mathrm{C}-\mathrm{CO}_{2}$ signature of the pore water, which is challenging to differentiate by the isotope-mass balance approach but impossible to notice in the resulting DIC concentration. In pore water samples obtained in the field, the fraction of $\mathrm{CO}_{2}$ derived from methanogenesis was calculated by the isotope-mass balance to be 2.75 times those registered by the $\mathrm{CO}_{2}$ concentration in the pore water. It would be reflecting the proportion of methane that is lost by oxidation, which was very stable in all studied mangrove sites. Closed-system incubations clearly showed that this $\mathrm{CH}_{4}$ should be lost by anaerobic oxidation. The mismatch observed in these laboratory assays among both approaches should probably be related to the addition/consumption of $\mathrm{CO}_{2}$ from other non-fractionating processes. For example, Ref.[13] found a high agreement between both partitioning methods (concentration and isotope-mass balances) because, in their freshwater wetlands, other non-fractionating processes, such as AOM were rather unlikely. However, anaerobic conditions imposed during laboratory incubations demonstrated that these other non-fractionating processes could be substantial, supposing $30-35 \%$ of $\mathrm{CO}_{2}$ was released. Other non-fractionating processes that may be present in our mangrove wetlands include other electron acceptors such as humics, nitrate, iron, and sulfate reduction, but they could hardly be differentiated.

\subsection{Dominance of Aerobic versus Anaerobic Respiration in Mangrove Soils}

According to the isotope-mass balances of pore water samples collected in the field, the main pathway of the organic matter degradation changes significantly from one ecosystem 
to another, being highly variable within the systems most altered by aquaculture activity: in mangrove soils close to shrimp-farm effluents methanogenesis increases (MEL-1 and DOM-1, Table 2). On the contrary, in pristine mangroves such as ALG, methanogenesis decreases comparatively and suppose $26-33 \%$ of the $\mathrm{CO}_{2}$ produced. This pattern of fermentation disappeared when mangrove soil samples were incubated under anaerobic conditions, and all mangrove sites exhibited a similar dominance of methanogenesis versus respiration (65-72\%). Microbial decomposition in mangroves has been cited to be mainly governed by external drivers, such as the prevailing tidal regime [56]. However, results demonstrated that methanogenesis in our mangroves strongly depends on soil environmental conditions. Since there were no differences in the organic matter content of the soils, and the nutrients do not stimulate methane production, it seems feasible that the reduction in methanogenesis was due to the supply of oxygen by the roots of the mangroves in the best-preserved mangrove forests of ALG, as the statistical relationship with the basal area of mangrove forests indicated. The importance of the oxygen supply provided by mangrove roots in organic matter degradation has been previously suggested [54], but our results show how it can even be very efficient in limiting methane production. This is a relevant finding because the mangrove forest degradation or clearing has implications on greenhouse gas emissions.

Experiments in rice fields indicated methane production increases in silty-loam soils [57]. Our results partially support this finding, although our experiments and field observations have not fully captured this pattern. The sandiest texture observed in mangrove soils most influenced by shrimp-farm effluent could be explained by discharges that usually have a high load of suspended solids (e.g., [58]), but there was no available data to confirm this.

It is believed that anthropogenic impacts, such as increased organic and nutrient loading, may increase methane emissions from mangroves through the induction of severe oxygen stress and the supply of labile organic carbon [54]. Although our results obtained by the incubations revealed a limitation of methanogenesis with nutrient enrichment, they are likely an artifact derived from the closed-system experimentation. Isotope-mass balances of field samples collected from mini piezometers indicated that the fraction of $\mathrm{CO}_{2}$ derived from methanogenesis was higher at sites located closer to nutrient-rich shrimpfarm effluents, which exhibited higher concentrations of $\mathrm{N}$ and $\mathrm{P}$ on their pore waters.

Studies have highlighted the importance of freshwater inputs on methane production and emission in mangroves (e.g., [59-61]). Our results demonstrated that methanogenesis occurs as an active process in all the mangrove soil studied despite the absence of freshwater inputs in this arid coastal area. A similar independence of freshwater inputs in methane production was previously cited in other mangroves [62]. Therefore, this would indicate that the presence of sulfate in the soils of coastal wetlands is not so critical in the production of methane as previously thought, but both processes co-occur in different soil places and are strongly coupled instead.

\subsection{Methanogenesis Pathways and Shifts Derived by Shrimp-Farming}

Isotope-mass balances indicated shifts in the two main pathways of methane production among mangroves related to organic matter quality available in each soil mangrove. In the most-impacted sites (MEL), methanogenesis mainly occurs from $\mathrm{CO}_{2}$ reduction, whereas in the most pristine mangrove (ALG), the acetoclastic pathway dominated. In freshwaters, it has been suggested that complete mineralization under methanogenic conditions generally produces $2 / 3$ of $\mathrm{CH}_{4}$ by the acetoclastic pathway and $1 / 3$ by the hydrogenotrophic route [63]. This fractionation agrees with our results found in ALG. On the other hand, incomplete mineralization may preferentially produce $\mathrm{CH}_{4}$ from $\mathrm{CO}_{2}$ reduction, which partially concurs with the observed in the MEL site. Furthermore, acetate fermentation is associated with methane production from labile organic matter, whereas the hydrogenotrophic methanogenic pathway uses more refractory organic fraction $[64,65]$. In this region, a common practice in aquaculture is the discharge of effluents into the 
coastal water bodies, to be captured again by pumping towards the shrimp farms in a recirculation effect of eutrophic waters [66]. This practice adds more organic matter to the system. However, because organic matter is highly exploited within the shrimp-farm system, effluents are enriched in the refractory organic matter $[67,68]$; it is likely that this alteration affects metabolic processes, such as the methane production pathways. The quantitative effects of this shift in the methanogenesis pathway are not yet clear, nor is it clear if this response is a generalized pattern in all mangrove soils receiving shrimp farm effluents, given what was observed in the other impacted mangrove DOM. According to the $\delta^{13} \mathrm{C}-\mathrm{CO}_{2}$ mass balances, the increase in the refractory organic matter does not seem to affect the amount of methane produced, and this would be a marginal factor, but the long-term effects are unexplored in mangroves.

\subsection{Alternative Non-Competitive Substrates for Methanogenesis in Mangroves}

Sulfate reduction, which is accomplished by strictly anaerobic microorganisms, is recognized as the second most crucial respiratory process after aerobic respiration involved in the decomposition of mangrove-derived soil organic matter [54]. Sulfate-reducing bacteria outcompete methanogens for common substrates, such as acetate or $\mathrm{H}_{2} / \mathrm{CO}_{2}$ [69]. Consequently, the methane production zone has been located deeper within the sediment below the sulfate reduction zone [3]. However, various studies demonstrated the co-existence of dissolved methane and sulfate in mangrove soils due to the ability of methanogenic microorganisms to use non-competitive substrates, such as methylated compounds (e.g., methanol), which cannot be used by sulfate-reducing bacteria [15,70]. Although it is generally accepted that only a minor portion of the methane released from the environment originates from methylotrophic methanogenesis [71], in mangroves exposed to shrimpfarm effluent discharges, this pathway could be of interest, considering the effects derived on the supply of organic matter quality. Unfortunately, the stoichiometry of the production of methane and $\mathrm{CO}_{2}$ from methanol is uneven (3:1) [72], and the isotopic-mass balance of $\mathrm{CO}_{2}$ cannot be used according to our assumptions to assess the effects.

Methylotrophic methanogens fractionate carbon isotopes very strongly during the methanogenic conversion of methanol and have $\varepsilon$ values covering a range of around $-83 \%$ to $-72 \%$ [72]. The isotope-mass balance estimated a domain of the hydrogenotrophic methanogenesis pathway in MEL sites, although the isotope separations were within the range of the methylotrophic methanogenesis pathway (MEL-2 and MEL-3; Table 3). In mangroves in Yucatán (Mexico), the co-occurrence of methane and sulfate reduction in shallow sediments has been explained by high methane production rates supported by methylotrophic methanogens [15]. Nevertheless, independently of the pathway, the low concentration of methane measured in the soil pore waters of our mangroves appeared more related to intense methane oxidation under anaerobic conditions. Regardless, much is still unknown about the scope of these non-competitive substrates in the metabolism of the anaerobic zone, their immediate effects, and whether they contribute to reducing or enhancing methane emissions from mangroves.

\subsection{Sulfate Reduction Coupled to AOM in Mangroves}

As cited above, $\delta^{13} \mathrm{C}-\mathrm{CO}_{2}$ mass balances indicated high $\mathrm{CH}_{4}$ production in all studied mangrove soils, which should be intensively lost to the atmosphere or oxidized given the lower concentration measured in soil pore waters. [6] described no detectable methane emission in similar mangrove soils located in Baja California Sur (Mexico), which should be explained by balancing methane production and oxidation. Our observations in all mangrove sites suggest the co-existence of methanogens with sulfate reducers in a skinny layer of soil below $14 \mathrm{~cm}$ of soil depth where the pore water was collected from mini piezometers. In terms of $\mathrm{CH}_{4}$ consumption in coastal ecosystems, anaerobic methane-oxidizing archaea, probably associated with sulfate-reducing bacteria, are relatively important compared with the aerobic methylotrophs [73]. Although AOM coupled to sulfate reduction has been well documented in other coastal wetlands (e.g., [3]), it has not been well documented 
in the mangrove soils. AOM coupled to sulfate reduction is a syntrophic process carried out by three novel groups of archaea putative called anaerobic methanotrophs (ANME), whose cells have been found to contain most of the genes typically associated with $\mathrm{CH}_{4}$ production and which probably mediate a form of reversed methanogenesis since AOM, like methanogenesis [74].

Moreover, methanogens have been found to mediate $\mathrm{CH}_{4}$ oxidation during net methanogenesis [75]. Therefore, during AOM coupled to sulfate reduction, ANME converts $\mathrm{CH}_{4}$ to a metabolite, which forms the electron donor for the sulfate-reducing bacterial partner. Recent findings pointed out the involvement of more than one intermediate interspecies electron carrier and that electron shuttling is transferred via extracellular redox shuttles [76] or via membrane-bound redox shuttles ("nanowires"; [77]) or mediated by humic substances [78]. While evidence of these aspects and their quantitative importance in the oxidation of methane have been obtained, the most relevant aspect is the mechanism of electron transfer, explaining the co-occurrence of AOM and sulfate reduction. Electrical currents in marine sediments couple spatially separated biogeochemical processes, presumably through nanowires; it could be expected to also occur in mangrove soils, explaining the coupling of ANME and sulfate reduction bacteria without existing direct physical contact [79]. Moreover, the increase in the refractory organic matter associated with shrimp-farm effluent discharges and the multiple pieces of evidence that electron-accepting functional groups present in humus (the recalcitrant fraction of the natural organic matter with redox activity) fuels AOM [78,80]; the potential effect of this shift on $\mathrm{CH}_{4}$ consuming processes need to be explored further.

\section{Conclusions}

Methane concentration in mangrove soil pore waters is often so low that it prevents emissions. Quantifying both methane production and its anaerobic oxidation in mangroves is subject to uncertainty since most involved processes are unknown. A detailed understanding of in situ isotope signatures of methane is confronted with further complications associated with the fractionation factors of each process in which methane is involved (production and consumption), including those derived from the substrate used by methanogens depending on the pathway and those from the electron acceptors occurring during the oxidation under anaerobic conditions (sulfate, nitrate/nitrite, and humic substances) $[17,80]$. The $\delta^{13} \mathrm{C}$ isotope approach used here through the $\delta^{13} \mathrm{C}-\mathrm{CO}_{2}$ mass balance of the pore waters demonstrated that methane production is an active process in mangroves, but this methane is probably oxidized anaerobically according to the potential rates measured in closed-system incubations. Several signs indicated the occurrence of AOM coupled to sulfate reduction, but the total role of the sulfur cycle in $\mathrm{CH}_{4}$-consuming processes must be addressed in future studies. Results obtained from the isotopic mass balances revealed no significant influence of shrimp-farm effluents on methane production, except by an apparent effect on the supply of a more recalcitrant organic matter, which forced methanogens to shift the main pathway. It should not affect the AOM either, considering various laboratory assays had shown that it is fueled when humic substances were added. This study confirmed previous findings on the microbial processes in mangrove soils, which exhibit strong resilience towards disturbances.

Author Contributions: Conceptualization, S.S.-C.; methodology, S.S.-C., R.S.-A. and J.G.-P.; investigation, S.S.-C., R.S.-A., J.G.-P., F.J.C., M.C.B., M.M.-I. and F.T.; resources, S.S.-C., R.S.-A., J.G.-P., F.J.C. and F.T.; data curation, S.S.-C., R.S.-A., J.G.-P., F.J.C., M.C.B., M.M.-I. and F.T.; writing-original draft preparation, S.S.-C.; writing-review and editing, S.S.-C., R.S.-A., J.G.-P., F.J.C., M.C.B., M.M.-I. and F.T.; funding acquisition, J.G.-P. and S.S.-C. All authors have read and agreed to the published version of the manuscript.

Funding: CONACyT: PROFAPI, Spanish Ministry of Science and Innovation (Grant: CGL2014-54502) and CSIC (Grant: I-COOP+2020-COOPA20433) funded this research.

Institutional Review Board Statement: Not applicable. 
Informed Consent Statement: Not applicable.

Data Availability Statement: Data available on request due to restrictions. The data presented in this study are available on request from the corresponding author. The data are not publicly available due to restrictions.

Acknowledgments: We thank Masuly Vega, Miguel A. Rivera, David H. Encinas, Sebastian Encinas, and Kevin Carrillo for their support during field campaign and laboratory tests. Additionally, we recognize the support provided by Joy Matthews and Rick Doucett at the Stable Isotope Facility of UC-Davis and by Chris Eastoe at the Environmental Isotope Laboratory of the University of Arizona. This study was developed during a stay of SSC at ITSON, who is grateful for the support provided.

Conflicts of Interest: The authors declare no conflict of interest.

\section{References}

1. Denman, K.L.; Brasseur, G.; Chidthaisong, A.; Ciais, P.; Cox, P.M.; Dickinson, R.E.; Hauglustaine, D.; Heinze, C.; Holland, E.; Jacob, D.; et al. Couplings Between Changes in the Climate System and Biogeochemistry. In Climate Change 2007: The Physical Science Basis. Contribution of Working Group I to the Fourth Assessment Report of the Intergovernmental Panel on Climate Change; Solomon, S., Qin, D., Manning, M., Chen, Z., Marquis, M., Averyt, K.B., Tignor, M., Miller, H.L., Eds.; Cambridge University Press: Cambridge, UK, 2007; pp. 499-587.

2. Chasar, L.S.; Chanton, J.P.; Glaser, P.H.; Siegel, D.I. Methane concentration and stable isotope distribution as evidence of rhizospheric processes: Comparison of a fen and bog in the Glacial Lake Agassiz Peatland Complex. Ann. Bot. 2000, 86, 655-663. [CrossRef]

3. Segarra, K.E.A.; Comerford, C.; Slaughter, J.; Joye, S.B. Impact of electron acceptor availability on the anaerobic oxidation of methane in coastal freshwater and brackish wetland sediments. Geochim. Cosmochim. Ac. 2013, 115, 15-30. [CrossRef]

4. Verma, A.; Subramanian, V.; Ramesh, R. Methane emissions from a coastal lagoon: Vembanad Lake, West Coast, India. Chemosphere 2002, 47, 883-889. [CrossRef]

5. Kreuzwieser, J.; Buchholz, J.; Rennenberg, H. Emission of methane and nitrous oxide by Australian mangrove ecosystems. Plant Biol. 2003, 5, 423-431. [CrossRef]

6. Giani, L.; Dittrich, K.; Marstfeld-hartmann, A.; Peters, G. Methanogenesis in salt marsh soils of the North Sea coast of Germany. Eur. J. Soil Sci. 1996, 47, 175-182. [CrossRef]

7. Alongi, D.M.; Wattayakorn, G.; Pfitzner, J.; Tirendi, F.; Zagorskis, I.; Brunskill, G.J.; Davidson, A.; Clough, B.F. Organic carbon accumulation and metabolic pathways in sediments of mangrove forests in southern Thailand. Mar. Geol. 2001, 179, 85-103. [CrossRef]

8. Furtado, A.L.S.; Casper, P.; Assis, F. Methanogenesis in an impacted and two dystrophic coastal lagoons (Macaé, Brazil). Braz. Arch. Biol. Technol. 2002, 45, 195-202. [CrossRef]

9. Sotomayor, D.; Corredor, J.E.; Morell, J.M. Methane flux from mangrove sediments along the Southwestern coast of Puerto Rico. Estuaries 1994, 17, 140-147. [CrossRef]

10. Allen, D.E.; Dalal, R.C.; Rennenberg, H.; Meyer, R.L.; Reeves, S.; Schmidt, S. Spatial and temporal variation of nitrous oxide and methane flux between subtropical mangrove sediments and the atmosphere. Soil Biol. Biochem. 2007, 39, 622-631. [CrossRef]

11. Biswas, H.; Mukhopadhyay, S.K.; Sen, S.; Jana, T.K. Spatial and temporal patterns of methane dynamics in the tropical mangrove dominated estuary, NE coast of bay of Bengal, India. J. Mar. Sys. 2007, 68, 55-64. [CrossRef]

12. Linto, N.; Barnes, J.; Ramachandran, R.; Divia, J.; Purvaja, R.; Upstill-Goddard, R.C. Carbon dioxide and methane emissions from mangrove-associated waters of the Andaman Islands, Bay of Bengal. Estuar. Coast. 2014, 37, 381-398. [CrossRef]

13. Call, M.; Maher, D.T.; Santos, I.R.; Ruiz-Halpern, S.; Mangion, P.; Sanders, C.J.; Erler, D.V.; Oakes, J.M.; Rosentreter, J.; Murray, R.; et al. Spatial and temporal variability of carbon dioxide and methane fluxes over semi-diurnal and spring-neap-spring timescales in a mangrove creek. Geochim. Cosmochim. Ac. 2015, 150, 211-225. [CrossRef]

14. Lee, R.; Porubsky, W.; Feller, I.; McKee, K.; Joye, S. Pore water biogeochemistry and soil metabolism in dwarf red mangrove habitats (Twin Cays, Belize). Biogeochemistry 2008, 87, 181-198. [CrossRef]

15. Chuang, P.-C.; Young, M.B.; Dale, A.W.; Miller, L.G.; Herrera-Silveira, J.A.; Paytan, A. Methane and sulfate dynamics in sediments from mangrove-dominated tropical coastal lagoons, Yucatán, Mexico. Biogeosciences 2016, 13, 2981-3001. [CrossRef]

16. Cui, M.; Ma, A.; Qi, H.; Zhuang, X.; Zhuang, G. Anaerobic oxidation of methane: An "active" microbial process. Microbiologyopen 2015, 4, 1-11. [CrossRef]

17. Segarra, K.E.A.; Schubotz, F.; Samarkin, V.; Yoshinaga, M.Y.; Hinrichs, K.-U.; Joye, S.B. High rates of anaerobic methane oxidation in freshwater wetlands reduce potential atmospheric methane emissions. Nat. Commun. 2015, 6, 7477. [CrossRef]

18. Chanton, J.P.; Chasar, L.; Glaser, P.H.; Siegel, D.I. Carbon and hydrogen isotopic effects in microbial methane from terrestrial environments. In Stable Isotopes and Biosphere-Atmosphere Interactions, Physiological Ecology Series; Flanagan, L.B., Ehleringer, J.R., Pataki, D.E., Eds.; Elsevier: Amsterdam, The Netherlands, 2005; pp. 85-105.

19. Corbett, J.E.; Tfaily, M.M.; Burdige, D.J.; Cooper, W.T.; Glaser, P.H.; Chanton, J.P. Partitioning pathways of $\mathrm{CO}_{2}$ production in peatlands with stable carbon isotopes. Biogeochemistry 2013, 114, 327-340. [CrossRef] 
20. Shoemaker, J.K.; Schrag, D.P. Subsurface characterization of methane production and oxidation from a New Hampshire wetland. Geobiology 2010, 8, 234-243. [CrossRef]

21. Whiting, G.J.; Chanton, J.P. Primary production control of methane emission from wetlands. Nature 1993, 364, 794-795. [CrossRef]

22. Coles, J.R.P.; Yavitt, J.B. Control of methane metabolism in a forested Northern Wetland, New York State, by aeration, substrates, and peat size fractions. Geomicrobiol. J. 2002, 19, 293-315. [CrossRef]

23. Bastviken, D.; Cole, J.C.; Pace, M.; Tranvik, L. Methane emissions from lakes: Dependence of lake characteristics, two regional assessments, and a global estimate. Global Biogeochem. Cy. 2004, 18, GB4009. [CrossRef]

24. West, W.E.; Creamer, K.P.; Jones, S.E. Productivity and depth regulate lake contributions to atmospheric methane. Limnol. Oceanogr. 2016, 61, S51-S61. [CrossRef]

25. DelSontro, T.; Boutet, L.; StPierre, A.; del Giorgio, P.A.; Prairie, Y.T. Methane ebullition and diffusion from northern ponds and lakes regulated by the interaction between temperature and system productivity. Limnol. Oceanogr. 2016, 61, S62-S77. [CrossRef]

26. DelSontro, T.; Beaulieu, J.J.; Downing, J.A. Greenhouse gas emissions from lakes and impoundments: Upscaling in the face of global change. Limnol. Oceanogr. Lett. 2018, 3, 64-75. [CrossRef]

27. Kristensen, E.; Mangion, P.; Tang, M.; Flindt, M.R.; Holmer, M.; Ulomi, S. Microbial carbon oxidation rates and pathways in sediments of two Tanzanian mangrove forests. Biogeochemistry 2011, 103, 143-158. [CrossRef]

28. Chen, G.C.; Tam, N.F.Y.; Wong, Y.S.; Ye, Y. Effect of wastewater discharge on greenhouse gas fluxes from mangrove soils. Atmos. Environ. 2011, 45, 1110-1115. [CrossRef]

29. Chen, G.; Chen, B.; Yu, D.; Tam, N.F.Y.; Ye, Y.; Chen, S. Soil greenhouse gas emissions reduce the contribution of mangrove plants to the atmospheric cooling effect. Environ. Res. Lett. 2016, 11, 124019. [CrossRef]

30. Casillas-Hernández, R.; Nolasco-Soria, H.; García-Galano, T.; Carrillo-Farnes, O.; Páez-Osuna, F. Water quality, chemical fluxes and production in semi-intensive Pacific white shrimp (Litopenaeus vannamei) culture ponds utilizing two different feeding strategies. Aquac. Eng. 2007, 36, 105-114. [CrossRef]

31. Barraza-Guardado, R.H.; Arreola-Lizárraga, J.A.; López-Torres, M.A.; Casillas-Hernández, R.; Miranda-Baeza, A.; Magallón-Barrajas, F.; Ibarra-Gómez, C. Effluents of shrimp farms and its influence on the coastal ecosystems of Bahía de Kino Mexico. Sci. World J. 2013, 2013, 306370. [CrossRef] [PubMed]

32. Ruiz, J.M.; Pérez, M.; Romero, J. Effects of fish farm loadings on seagrass (Posidonia oceanica) distribution, growth and photosynthesis. Mar. Pollut. Bull. 2001, 42, 749-760. [CrossRef]

33. Páez-Osuna, F.; Gracia, A.; Flores-Verdugo, F.; Lyle-Fritch, L.P.; Alonso-Rodríguez, R.; Roque, A.; Ruiz-Fernández, A.C. Shrimp aquaculture development and the environment in the Gulf of California ecoregion. Mar. Pollut. Bull. 2003, 46, 806-815. [CrossRef]

34. Serrano-Grijalva, L.; Sánchez-Carrillo, S.; Angeler, D.G.; Sanchez-Andres, R.; Alvarez-Cobelas, M. Effects of shrimpfarm effluents on the food web structure in subtropical coastal lagoons. J. Exp. Mar. Biol. Ecol. 2011, 402, 65-74. [CrossRef]

35. Aschenbroich, A.; Marchand, C.; Molnar, N.; Deborde, J.; Hubas, C.; Rybarczyk, H.; Meziane, T. Spatio-temporal variations in the composition of organic matter in surface sediments of a mangrove receiving shrimp farm effluents (New Caledonia). Sci. Total Environ. 2015, 512-513, 296-307. [CrossRef]

36. Nóbrega, G.N.; Ferreira, T.O.; Siqueira, M.; Hermano, N.; Queiroz, M.; Artur, A.G.; Mendonça, E.D.S.; Silva, E.D.O.; Oterof, X.L. Edaphic factors controlling summer (rainy season) greenhouse gas emissions $\left(\mathrm{CO}_{2}\right.$ and $\left.\mathrm{CH}_{4}\right)$ from semiarid mangrove soils (NE-Brazil). Sci. Total Environ. 2016, 542, 685-693. [CrossRef]

37. Sánchez-Carrillo, S.; Sánchez-Andrés, R.; Alatorre, L.C.; Angeler, D.G.; Álvarez-Cobelas, M.; Arreola-Lizárraga, J.A. Nutrient fluxes in a semi-arid microtidal mangrove wetland in the Gulf of California. Est. Coast. Shelf Sci. 2009, 82, 654-662. [CrossRef]

38. Steinbeck, J.; Ricketts, E.F. The Sea of Cortez. A Leisurely Journal of Travel and Research; Viking Press: New York, NY, USA, 1951.

39. Almada-Bay, I. Sonora 2000 a Debate: Problemas y Soluciones, Riesgos y Oportunidades; El Colegio de Sonora: Mexico DF, México, 2000.

40. Sánchez-Andrés, R.; Sánchez-Carrillo, S.; Alatorre, L.C.; Cirujano, S.; Álvarez-Cobelas, M. Litterfall dynamics and nutrient decomposition of arid mangroves in the Gulf of California: Their role sustaining ecosystem heterotrophy. Est. Coast. Shelf Sci. 2010, 89, 191-199. [CrossRef]

41. Teh, Y.A.; Silver, W.L.; Conrad, M.E.; Borglin, S.E.; Carlson, C.M. Carbon isotope fractionation by methane-oxidizing bacteria in tropical rain forest soils. J. Geophys. Res. Biogeosci. 2006, 111, G02001. [CrossRef]

42. Holler, T.; Wegener, G.; Knittel, K.; Boetius, A.; Brunner, B.; Kuypers, M.M.; Widdel, F. Substantial ${ }^{13} \mathrm{C} /{ }^{12} \mathrm{C}$ and D/H fractionation during anaerobic oxidation of methane by marine consortia enriched in vitro. Environ. Microbiol. Rep. 2009, 1, 370-376. [CrossRef] [PubMed]

43. Alperin, M.J.; Reeburgh, W.S.; Whiticar, M.J. Carbon and hydrogen isotope fractionation resulting from anaerobic methane oxidation. Global Biogeochem. Cy. 1988, 2, 279-288. [CrossRef]

44. Grasshoff, K.; Kremlingl, K.; Ehrhardt, M. (Eds.) Methods of Seawater Analysis, 3rd ed.; Wiley-VCH: Weinheim, Germany, 1999.

45. Jancsó, G. Interpretation of isotope effects on the solubility of gases. Nukleonika 2002, 243, 328-342. [CrossRef]

46. Bacsik, Z.; Lopes, J.N.C.; Gomes, M.F.C.; Jancso, G.; Mink, J.; Padua, A.A.H. Solubility isotope effects in aqueous solutions of methane. J. Chem. Phys. 2002, 116, 10816-10824. [CrossRef]

47. Garcia-Tigreros Kodovska, F.; Sparrow, K.J.; Yvon-Lewis, S.A.; Paytan, A.; Dimova, N.T.; Lecher, A.; Kessler, J.D. Dissolved methane and carbon dioxide fluxes in Subarctic and Arctic regions: Assessing measurement techniques and spatial gradients. Earth Planet. Sc. Lett. 2016, 436, 43-55. [CrossRef] 
48. Knox, M.; Quay, P.D.; Wilbur, D. Kinetic isotopic fractionation during air-water gas transfer of $\mathrm{O}_{2}, \mathrm{~N}_{2}, \mathrm{CH}_{4}$, and $\mathrm{H}_{2}$. J. Geophys. Res. 1992, 97, 20335-20343. [CrossRef]

49. Conrad, R.; Chan, O.C.; Claus, P.; Casper, P. Characterization of methanogenic Archaea and stable isotope fractionation during methane production in the profundal sediment of an oligotrophic lake (Lake Stechlin, Germany). Limnol. Oceanogr. 2007, 52, 1393-1406. [CrossRef]

50. Cintron, G.; Lugo, A.E.; Pool, D.J.; Morris, G. Mangroves of arid environments in Puerto Rico and adjacent islands. Biotropica 1978, 10, 110-121. [CrossRef]

51. Holdridge, L.; Grenke, R.; Hathaway, W.C.; Liang, W.H.; Tosi, T. Forest Environments in Tropical Life Zone: A Pilot Study; Pergamon Press: New York, NY, USA, 1971.

52. Howard, R.F.; Singer, M.J. Measuring forest soil bulk density using irregular hole, paraffin clod, and air permeability. Forest Sci. 1981, 27, 316-322.

53. Bouyoucos, G.J. Hydrometer method improved for making particle size analyses of soils. Agron. J. 1962, 54, 464-465. [CrossRef]

54. Kristensen, E.; Bouillon, S.; Dittmar, T.; Marchand, C. Organic carbon dynamics in mangrove ecosystems: A review. Aquat. Bot. 2008, 89, 201-219. [CrossRef]

55. Jørgensen, B.B.; Kasten, S. Sulfur cycling and methane oxidation. In Marine Geochemistry; Schulz, H.D., Zabel, M., Eds.; Springer: Berlin, Germany, 2006; pp. 271-310.

56. Keuskamp, J.A.; Feller, I.C.; Laanbroek, H.J.; Verhoeven, J.T.A.; Hefting, M.M. Short- and long-term effects of nutrient enrichment on microbial exoenzyme activity in mangrove peat. Soil Biol. Biogeochem. 2015, 81, 38-47. [CrossRef]

57. Brye, K.R.; Rogers, C.W.; Smartt, A.D.; Norman, R.J. Soil texture effects on methane emissions from direct-seeded, delayed-flood rice production in Arkansas. Soil Sci. 2013, 178, 519-529. [CrossRef]

58. Roversi, F.; van Maanen, B.; Colonna Rosman, P.C.; Freitas Neves, C.; Scudelari, A.C. N umerical modeling evaluation of the impacts of shrimp farming operations on long-term coastal lagoon morphodynamics. Estuar. Coast. 2020, 43, 1853-1872. [CrossRef]

59. Villa, J.A.; Mitsch, W.J. Carbon sequestration in different wetland plant communities in Southwest Florida. Ecosyst. Serv. Managem. 2015, 11, 17-28.

60. Pereyra, A.S.; Mitsch, W.J. Methane emissions from freshwater cypress (Taxodium distichum) swamp soils with natural and impacted hydroperiods in Southwest Florida. Ecol. Eng. 2018, 114, 46-56. [CrossRef]

61. Hernández, M.E.; Junca-Gómez, D. Carbon stocks and greenhouse gas emissions $\left(\mathrm{CH}_{4}\right.$ and $\left.\mathrm{N}_{2} \mathrm{O}\right)$ in mangroves with different vegetation assemblies in the central coastal plain of Veracruz Mexico. Sci. Total Environ. 2020, 741, 140276. [CrossRef] [PubMed]

62. Cabezas, A.; Mitsch, W.J.; MacDonnell, C.; Zhang, L.; Bydałeka, F.; Lasso, A. Methane emissions from mangrove soils in hydrologically disturbed and reference mangrove tidal creeks in Southwest Florida. Ecol. Eng. 2018, 114, 57-65. [CrossRef]

63. Conrad, R.; Claus, P.; Casper, P. Characterization of stable isotope fractionation during methane production in the sediment of a eutrophic lake, Lake Dagow, Germany. Limnol. Oceanog. 2009, 54, 457-471. [CrossRef]

64. Hornibrook, E.R.C.; Longstaffe, F.J.; Fyfe, W.S. Evolution of stable carbon isotope compositions for methane and carbon dioxide in freshwater wetlands and other anaerobic environments. Geochim. Cosmochim. Acta 2000, 64, 1013-1027. [CrossRef]

65. Kumar, A.; Sharma, M.P. Estimation of green house gas emissions from Koteshwarhydropower reservoir, India. Environ. Monit. Assess. 2017, 189, 240. [CrossRef]

66. Anaya-Rosas, R.E. Cultivo de Camarón Blanco, Litopenaeus Vannamei, Boone (1931), en Sistema Cerrado a Alta Densidad. MSc Thesis, CICESE, Ensenada, Mexico. 2005. Available online: https://cicese.repositorioinstitucional.mx/jspui/bitstream/1007/114 4/1/167251.pdf (accessed on 3 July 2021).

67. Otoshi, C.; Tang, L.R.; Dagdagan, D.V.; Holl, C.M.; Tallamy, C.J.; Moss, D.R.; Acre, S.M.; Moss, S.M. Super-intensive growout of the Pacific white shrimp Litopenaeus vannamei: Recent advances at the Oceanic Institute. In Proceedings of the 6th International Conference on Recirculating Aquaculture, Tokyo, Japan, 11-12 November 2021; Rakestraw, T., Douglas, L., Flick, G., Eds.; Virginia Polytechnic Institute and State University: Blacksburg, VA, USA, 2006; pp. 1-5.

68. Beardsley, C.; Moss, S.; Malfatti, F.; Azam, F. Quantitative role of shrimp fecal bacteria in organic matter fluxes in a recirculating shrimp aquaculture system. FEMS Microbiol. Ecol. 2011, 77, 134-145. [CrossRef]

69. Oremland, R.S.; Polcin, S. Methanogenesis and sulfate reduction-Competitive and non competitive substrates in estuarine sediments. Appl. Environ. Microb. 1982, 44, 1270-1276. [CrossRef]

70. Parkes, R.J.; Brock, F.; Banning, N.; Hornibrook, E.R.C.; Roussel, E.G.; Weightman, A.J.; Fry, J.C. Changes in methanogenic substrate utilization and communities with depth in a salt-marsh, creek sediment in southern England. Estuar. Coast. Shelf. S. 2012, 96, 170-178. [CrossRef]

71. Conrad, R.; Claus, P. Contribution of methanol to the production of methane and its C-13-isotopic signature in anoxic rice field soil. Biogeochemistry 2005, 73, 381-393. [CrossRef]

72. Penger, J.; Conrad, R.; Blaser, M. Stable carbon isotope fractionation by methylotrophic methanogenic archaea. Appl. Environ. Microbiol. 2012, 78, 7596-7602. [CrossRef] [PubMed]

73. Hoehler, T.M.; Alperin, M.J.; Albert, D.B.; Martens, C.S. Apparent minimum free energy requirements for methanogenic Archaea and sulfate-reducing bacteria in an anoxic marine sediment. FEMS Microbiol. Ecol. 2001, 38, 33-41. [CrossRef]

74. Nauhaus, K.; Treude, T.; Boetius, A.; Krüger, M. Environmental regulation of the anaerobic oxidation of methane: A comparison of ANME-1 and ANME-2 communities. Environ. Microbiol. 2005, 71, 98-106. [CrossRef] 
75. Meulepas, R.J.W.; Jagersma, C.G.; Zhang, Y.; Petrillo, M.; Cai, H.; Buisman, C.J.N.; Stams, A.J.M.; Lens, P.N.L. Trace methane oxidation and the methane-dependency of sulfate reduction in anaerobic granular sludge. FEMS Microbiol. Ecol. 2010, 72, 261-271. [CrossRef] [PubMed]

76. Wegener, G.; Niemann, H.; Elvert, M.; Hinrichs, K.-U.; Boetius, A. Assimilation of methane and inorganic carbon by microbial communities mediating the anaerobic oxidation of methane. Environ. Microbiol. 2008, 10, 2287-2298. [CrossRef] [PubMed]

77. Meulepas, R.J.; Jagersma, C.G.; Khadem, A.F.; Stams, A.J.; Lens, P.N. Effect of methanogenic substrates on anaerobic oxidation of methane and sulfate reduction by an anaerobic methanotrophic enrichment. Appl. Microbiol. Biotechnol. 2010, 87, 1499-1506. [CrossRef]

78. Valenzuela, E.I.; Avendaño, K.A.; Balagurusamy, N.; Arriaga, S.; Nieto-Delgado, C.; Thalasso, F.; Cervantes, F.J. Electron shuttling mediated by humic substances fuels anaerobic methane oxidation and carbon burial in wetland sediments. Sci. Total Environ. 2019, 650, 2674-2684. [CrossRef]

79. Nielsen, L.P.; Risgaard-Petersen, N.; Fossing, H.; Christensen, P.B.; Sayama, M. Electric currents couple spatially separated biogeochemical processes in marine sediment. Nature 2010, 463, 1071-1074. [CrossRef]

80. Valenzuela, E.I.; Prieto-Davó, A.; López-Lozano, N.E.; Hernández-Eligio, A.; Vega-Alvarado, L.; Juárez, K.; García-González, A.S.; López, M.G.; Cervantes, F.J. Anaerobic methane oxidation driven by microbial reduction of natural organic matter in a tropical wetland. Appl. Environ. Microbiol. 2017, 83, e00645-17. [CrossRef] [PubMed] 